\title{
A Reporting Quality Assessment of Systematic Reviews and Meta-Analyses in Sports Physical Therapy: A Review of Reviews
}

\author{
Sung-Hyoun Cho ${ }^{1}$ and In-Soo Shin ${ }^{2, *(D)}$ \\ 1 Department of Physical Therapy, Nambu University, 23 Cheomdan Jungang-ro, Gwangsan-gu, \\ Gwangju 62271, Korea; shcho@nambu.ac.kr \\ 2 AI Convergence Education, Graduate School of Education, Dongguk University, 30, Pildong-ro 1 gil, Jung-gu, \\ Seoul 04620, Korea \\ * Correspondence: s9065031@dongguk.edu; Tel.: +82-10-4183-3168
}

Citation: Cho, S.-H.; Shin, I.-S. A Reporting Quality Assessment of Systematic Reviews and

Meta-Analyses in Sports Physical Therapy: A Review of Reviews.

Healthcare 2021, 9, 1368. https:// doi.org/10.3390/healthcare9101368

Academic Editor: Filipe

Manuel Clemente

Received: 31 July 2021

Accepted: 11 October 2021

Published: 14 October 2021

Publisher's Note: MDPI stays neutral with regard to jurisdictional claims in published maps and institutional affiliations.

\begin{abstract}
This review of reviews aimed to evaluate the reporting quality of published systematic reviews and meta-analyses in the field of sports physical therapy using the Preferred Reporting Items for Systematic Reviews and Meta-Analyses (PRISMA) guidelines. This review of reviews included a literature search; in total, 2047 studies published between January 2015 and December 2020 in the top three journals related to sports physical therapy were screened. Among the 125 identified articles, 47 studies on sports physical therapy were included in the analysis ( 2 systematic reviews and 45 meta-analyses). There were several problems areas, including a lack of reporting for key components of the structured summary $(10 / 47,21.3 \%)$, protocol and registration $(18 / 47,38.3 \%)$, risk of bias in individual studies $(28 / 47,59.6 \%)$, risk of bias across studies $(24 / 47,51.1 \%)$, effect size and variance calculations $(5 / 47,10.6 \%)$, additional analyses $(25 / 47,53.2 \%)$, and funding $(10 / 47,21.3 \%)$. The quality of the reporting of systematic reviews and meta-analyses of studies on sports physical therapy was low to moderate. For better evidence-based practice in sports physical therapy, both authors and readers should examine assumptions in more detail, and report valid and adequate results. The PRISMA guideline should be used more extensively to improve reporting practices in sports physical therapy.
\end{abstract}

Keywords: assessment; meta-analysis; systematic review; physical therapy; review of reviews

\section{Introduction}

Evidence-based practice (EBP) is the best decision-making method for patients [1]. The term "evidence-based medicine" was first introduced by Gordon Guyatt at McMaster University, in Canada in 1992 [2]. The Center of Evidence-Based Physiotherapy (CEBP), currently headquartered at the University of Sydney, Australia, was established in 1999 [3]. Clinicians should have the knowledge and skills to write and understand published systematic reviews and meta-analyses that will help better decision-making for patients [4]. Primary studies have several limitations in terms of clinical decision-making, e.g., a limited sample, mixed results, and inconsistent analytical methods and reporting [5]. Some scientific journals even tend to selectively publish thesis manuscripts with statistically significant results [6]. This may induce biases, such as result reporting bias, which may affect the validity of the results [4,7]. SRs and MAs overcome the limitations of primary studies [7].

Systematic reviews (SRs) and meta-analyses (Mas) are some of the best sources of evidence and scientific research, including clinical expertise and patient-reported outcomes [6]. The process of SR and MA includes problem formulation, literature search, data coding, and data analysis and reporting, which minimize the bias and increase transparency and reproducibility [8]. An SR is a literature review that collects, comprehensively analyzes, 
and evaluates all studies related to a research topic [9]. Therefore, if several clinical research papers show the same results through studies on the effect of the same treatment rather than a single clinical study, it provides a more accurate basis for the treatment effect than a single individual clinical study paper [10].

MA refers to a statistical method that synthesizes and analyzes quantitative research results extracted from multiple studies to produce summarized and organized empirical knowledge on a topic [7]. MA is a valid method for finding evidence so that clinicians and researchers can have a rationale for solving health-related problems [11]. Additionally, MA distinguishes the intervention effects of previous studies by characteristics and objectively compares them to develop intervention programs that can be successfully used in various practical fields [12].

SRs and MAs comprise the highest level in the evidence pyramid of medicine [13]. Systematic reviews (SRs) and meta-analyses (MAs) provide the best basis for use in decisionmaking regarding the application of medical service interventions $[6,14]$. Clinicians should have the knowledge and skills to write and understand published SRs and MAs, as this will aid in making better decisions with their patients [5].

The PRISMA (Preferred Reporting Items for Systematic Reviews and Meta-Analyses) guidelines detail what should be reported in MAs and SRs analyses [15]. However, the reporting quality of MAs and SRs in numerous clinical areas is low and very problematic [16-18]. Only one 2012 paper was found to analyze the reporting of SRs related to physical therapy, and it was also of very low quality [19].

Clinical intervention should be guided by scientific evidence, which should be obtained by valid and transparent processes and methods. Bias in the scientific process can lead to inappropriate clinical practices. Therefore, MAs and SRs should be conducted by referring to the PRISMA guidelines [20]. Quality assessment studies on MAs and RSs in other fields have been published. The purpose of this study is to indicate problems in research reporting methods and thus produce a more valid MA in sports physical therapy [20,21].

Interpreting the results of SRs and MAs should be performed carefully because the results may suffer from reporting study weakness [22]. There has been no quality reporting about SRs and MAs in the field of sports physical therapy research. Therefore, the purpose of this study was to evaluate the reporting quality of SRs and MAs published in the top three sports physical therapy journals [15]. This article summarized the major study results, the SRs and MAs method, and major findings and evaluated whether the reviewed articles aligned with the PRISMA guidelines' 27 items.

\section{Materials and Methods}

2.1. Eligibility and Exclusion Criteria

\subsubsection{Eligibility Criteria}

The top three journals in the field of sports physical therapy were selected based on the Journal Citation Reports impact factor (IF) index. The Journal of Orthopaedic \& Sports Physical Therapy, Journal of Athletic Training, and Physical Therapy in Sports ranked first, second, and third in this specific category of journals with IFs of 3.839, 2.478, and 1.926, respectively. The IF index measures the average number of citations received in a particular year by papers published in the journal during the preceding years of 2019 and 2020 [23]. The article selection criteria were as follows: (1) peer-reviewed articles published between January 2015 and December 2020, and (2) a statistical MA or systematic literature review of an intervention program.

\subsubsection{Exclusion Criteria}

As this study was not meant for clinical effect analysis, only treatment effect SRs from the three top journals were targeted. Narrative reviews, diagnostic test SRs, primary studies, qualitative review articles, authors' opinions, letters, and abstract presentations were excluded. 


\subsection{Information Sources and Search Strategy}

\subsubsection{Electronic Search}

We searched the Journal of Orthopaedic \& Sports Physical Therapy (https:/ /www. jospt.org, accessed on 31 April 2021), Journal of Athletic Training (https:/ / natajournals. org/loi/attr, accessed on 31 April 2021), and Physical Therapy in Sports (https:/ /www. journals.elsevier.com/physical-therapy-in-sport, accessed on 31 April 2021). The search strategy utilized a combination of medical subject heading (MeSH) terms and free text words, including "meta-analysis" (MeSH), "meta-analysis" (text word), "review" (MeSH), and "systematic review" (text words).

\subsubsection{Manual Search}

The included studies returned by the search, and previously published SRs and MAs related to the topic, were screened to identify any additional studies which could fit the criteria.

\subsection{Study Selection}

Publication details of all studies identified in the literature search were exported to EndNote (Endnote X9.3.3, Clarivate Analytics, Philadelphia, PA, USA). Once all records were imported, duplicates were removed. After that, titles and abstracts were independently screened for eligibility by the two authors using the specified inclusion and exclusion criteria. Full texts of the remaining articles were then sourced and independently evaluated for inclusion. Any disagreement was resolved through discussion.

\subsection{Data Collection Process and Data Item}

The PRISMA statement includes a checklist of 27 items [21], and the PRISMA checklist was used by the raters in the analyses of the eligible SRs [21]. For each checklist item, it was established that a rating of "yes" would only be assigned if the PRISMA statement recommendations were fully complied with. If the rater considered the information regarding any item to be incomplete, missing, or doubtful, that item was rated as "no." The quality evaluation criteria of this paper were identified as follows: "low quality," "moderate quality," and "high quality" when there was $<50 \%,<75 \%$, and $>75 \%$ agreement with the PRISMA checklist items, respectively [19,22,24-26].

The characteristics of the participants and interventions in the 47 selected articles were identified and coded per the research evaluation framework (Supplementary Materials Table S1) [19]. The articles were listed and outlined according to the coding table (Appendix A).

The two authors also independently extracted the following data from each included article into predesigned coding sheets: (1) study identification: the first author's name, location of the corresponding author(s), year of publication, and journal name; (2) number and design of the studies in the MA/SR; (3) population (participants); (4) interventions; (5) comparison between interventions; and (6) outcome measures. Discrepancies were resolved through discussion.

\subsection{Reliability of the Evaluators}

Two researchers independently checked each checklist item in a coding sheet and resolved discrepancies by consensus via weekly Zoom meetings. If the disagreement was not resolved, the researchers planned to consult a third coder to make the final decision. However, there were no disagreements between the coders in any of the items. Some items were not fulfilled according to the PRISMA checklist. The two researchers also evaluated additional reporting and statistical issues based on the PRISMA 2020 statement [27]. 


\subsection{Planned Methods of Analysis}

\subsubsection{Reporting of Epidemiological and Descriptive Characteristics}

The epidemiological and descriptive characteristics of the included MAs and SRs were assessed according to the journal type, corresponding author's location, number and design of included studies, population/patients/defects, type of intervention, comparison between interventions, outcome (Appendix A).

\subsubsection{Statistical Analysis}

Each PRISMA checklist item was presented as either the ratio or percentage of how many of the 47 PRISMA articles were properly followed (Appendix B).

\subsection{Ethical Statement}

This study was approved by the institutional review board of Nambu University (ethical code: 1041478-2017-HR-016; approval date: 8 November 2017) and was conducted in accordance with the ethical standards of the Declaration of Helsinki.

\section{Results}

\subsection{Study Selection}

A total of 2047 studies published by the Journal of Orthopaedic \& Sports Physical Therapy, Journal of Athletic Training, and Physical Therapy in Sports between January 2015 and December 2020 were considered. Among these, 47 articles listed as a systematic literature review or MA in the article category were initially selected. We excluded five narrative review articles, two articles that reported a rate, three articles that reported a ratio, two articles that reported the prevalence, one article that reported intraclass correlation coefficients, one article that reported reliability and validity, and one article that presented the diagnostic accuracy of a clinical test. Consequently, 47 articles were included in the final analysis (Appendix C) (Figure 1).

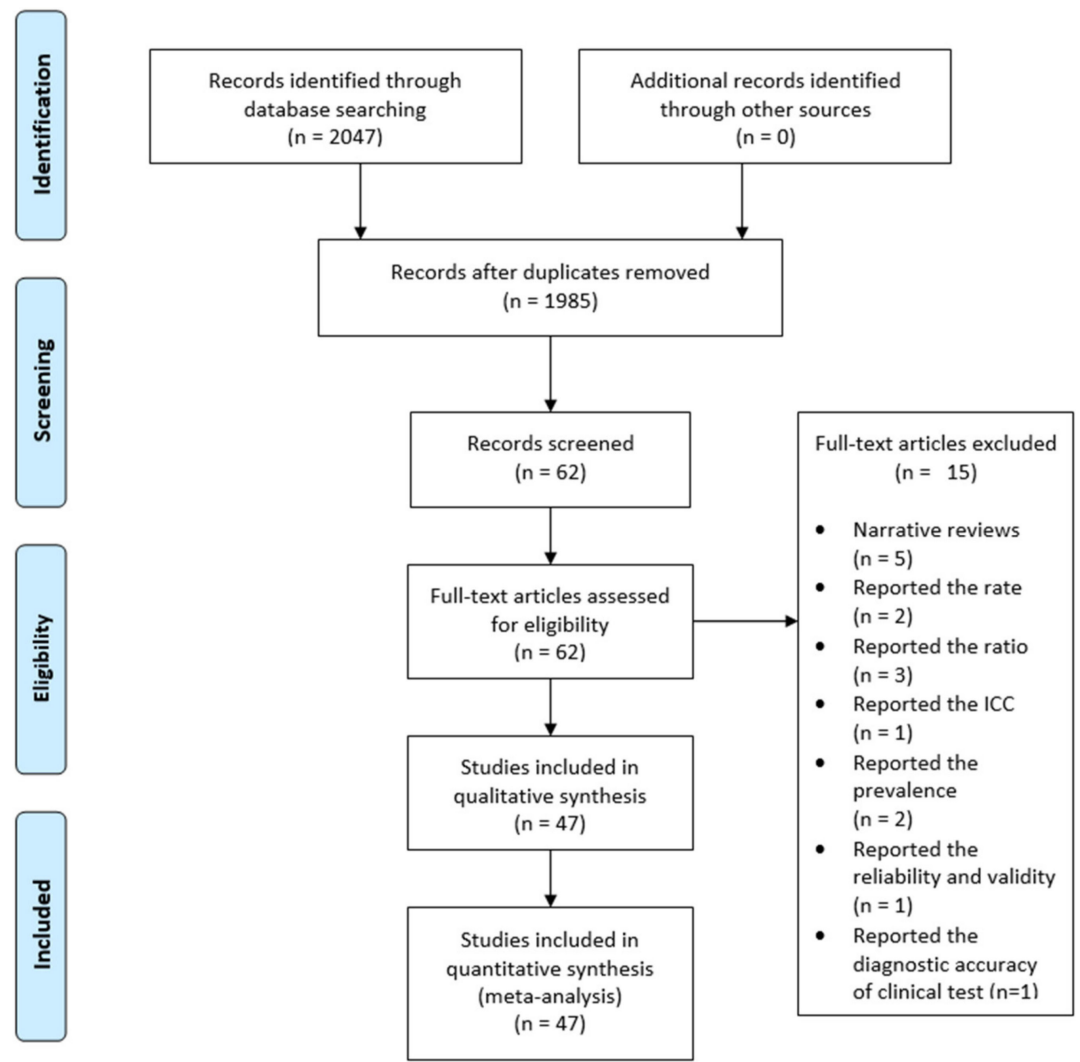

Figure 1. Flow chart describing the selection of the 47 articles after multiple phases of the screening process. ICC, intra-class correlation. 


\subsection{Study Characteristics}

\subsubsection{Epidemiological and Descriptive Characteristics}

MAs and SRs published in the Journal of Athletic Training, Journal of Orthopaedic \& Sports Physical Therapy, or Physical Therapy in Sports are shown in Appendix A. The types of interventions varied across the wide-ranging sports physical therapy field. The reporting guidelines used for the SR process also varied: $32(68.1 \%)$ articles used the PRISMA guidelines [15]. However, $15(31.9 \%)$ articles did not describe the reporting guidelines used. Regarding funding sources, 10 studies received private and/or public support $(21.3 \%)$, and 37 studies received no funding.

\subsubsection{General Characteristics of the Included Studies}

The main characteristics of all the included studies are described in Appendix A. The reporting quality of key components of the MAs and SRs, as evaluated based on the PRISMA guidelines, is shown in Appendix B. Two papers performed an SR, and the remaining 45 conducted a MA. Furthermore, 27 (57.4\%) studies included an RCT. Forty-two $(89.4 \%)$ studies used outcomes that were continuous variables, such as the mean change difference.

\subsection{Synthesis of the Results}

The evaluation results are described below in the following order: title, abstract, introduction, methods, results, and discussion (Appendix B).

Reporting of the General Components of the SR Process (27 Items)

To enhance the validity and impact of SRs, all authors and editors must apply established reporting standards. Thirty-two articles mentioned the application of a guideline and 15 articles did not. Thirty-two studies adhered to the PRISMA guidelines and two studies applied the 2015 PRISMA-P (Preferred Reporting Items for Systematic Reviews and Meta-analysis Protocols) guidelines [28,29]. One of the studies [28] mentioned the Measurement Tool to Assess Meta-analysis of Observational Studies in Epidemiology (MOOSE) [30].

Regarding item 2 (structured summary), we checked whether the abstract specifically presented the analytical model and effect size. Powden et al. specified that a fixed or randomized model was used [31]. Furthermore, studies that only reported the odds ratio $(\mathrm{OR})$, relative risk (95\% confidence interval [CI]), and effect size (Cohen's d, 95\% CI) in the data synthesis methods, and studies that did not present specific results (numbers) in the abstract, were considered to not have a structured summary (item 2). The PRISMA summary guidelines are a better source for this item published in 2013 [20].

In primary studies, researchers tend to report statistically significant results and emphasize a positive and large effect [32]. SRs and MAs have similar tendencies and, thus, require protocol registration to prevent selective reporting. Protocol registration is one of the methods that increase the validity of a MA [9]. Therefore, the protocols of SRs and MAs should be registered in PROSPERO (an international database of prospectively registered SRs in health and social care by the University of York, which is accessible to the public and researchers) [33], as for primary studies. However, no studies reported that the protocol was registered in PROSPERO or a local research foundation (item 5). For protocol and registration (item 5), none of the studies reported a selection/reporting bias.

The registration rate in the medical field is also very low, at 21\% [34]. Protocol registration should be emphasized because selective reporting can be evaluated by comparing the protocol against the full paper $[34,35]$. The National Institute for Health Research (NIHR) also supports protocol registration [36].

Twenty-eight (59.6\%) studies did not report the methods used to assess the risk of bias of studies (item 12). Furthermore, 23 (48.9\%) studies did not report the methods used to assess the risk of bias across studies (e.g., publication bias) (item 15), and 28 (59.6\%) studies did not describe the methods of additional analyses (item 16). Furthermore, more than half 
of the reviews did not report the "risk of bias within studies" (data presented on the risk of bias of each study and, if available, any outcome level assessment). This finding was also consistent with previous studies [22]. Reporting bias is crucial for assessing effect size because only advantageous results may be reported [37].

In the results section, $19(40.4 \%)$ studies did not present data on the risk of bias for each study and any outcome level assessment, if available (item 19), and 23 (48.9\%) did not report the risk of bias assessment across studies (item 22). Heterogeneity means the degree of differences in the results of each single research finding [38]. Through MAs, scholars calculate the heterogeneity index to understand the primary factors that impact individual studies' effect sizes [39]. For heterogeneity tests, $Q(34 / 47)$ and $\mathrm{I}^{2}$ inconsistency (38/47) statistics were used. Reporting on the effect size, most studies (42/47) did not provide the effect size formula, and no study reported the effect size variance formula in their methods section [40].

In this review, very few studies reported independent assumptions, missing data, or outliers, which should be addressed. Independent assumptions comprise two issues: first, whether the same sample was used twice or not, and second, how more than one effect size was treated in calculating an effect size for MA [40].

The results of additional analyses were mentioned in only 25 (53.2\%) studies (e.g., sensitivity or subgroup analyses and meta-regression analysis) (item 23). Forty-two articles did not describe a sensitivity analysis. The sensitivity analysis, used to test the reliability of the cumulative effect across included studies, revealed the effect sizes [41].

Interestingly, one study [42] evaluated the reviewed articles using the Grading of Recommendations Assessment, Development and Evaluation (GRADE) working group criteria after they completed their MA $[43,44]$. GRADE was used to investigate the overall quality of evidence for each outcome [45]. The MA evaluated the study's design, risk of bias and publication bias, consistency, the complexity of interventions, and roughness [46]. The Cochrane Handbook for Systematic Reviews of Interventions also supports the evaluation process by researchers who completed the reviews [14]. The GRADE criteria include five quality evaluations: (a) risk of bias, (b) inconsistency, (c) indirectness, (d) imprecision, and (e) publication bias [47].

In the discussion section, comments about the study limitations, outcome level, and review levels, such as the risk of bias and incomplete retrieval of identified research and funding, were not provided in $37(78.7 \%)$ studies (item 27). Many studies did not report a funding source. Research results can fundamentally differ according to funding sources. Funding bias refers to when a study's outcome is more likely to support the interests of the organization funding the study [48]. For example, studies regarding omega-3 supplementation for the prevention of cardiovascular disease, or the relationship between cell phone use and the risk of brain tumors, showed contrasting results depending on the funding source $[49,50]$. Most research indicates that sucralose is safe-except for research sponsored by competitors [51].

\section{Discussion}

This study was benchmarked against previous studies, which were mainly published in top journals according to the IF criteria related to the reporting quality assessment [52-55]. The trends of the last 5 years were assessed because the PRISMA-Diagnostic Test Accuracy, PRISMA-Rapid Reviews, PRISMA-Scoping Reviews, and PRISMA-Network MA guidelines were released in 2015. Thus, the current year was when systematic literature review and MA reporting standards began to be subdivided [56]. This review evaluated 47 MAs and SRs reported in the Journal of Orthopaedic \& Sports Physical Therapy, Journal of Athletic Training, and Physical Therapy in Sports related to sports physical therapy, using the PRISMA guidelines.

The study results were very similar compared to analyses of reporting of systematic reviews in physical therapy [19]. Analysis of reporting of systematic reviews in studies of reporting standards using the PRISMA statement have reported information regarding the 
risk of bias, protocol and registration, additional analysis, and funding was insufficient in quality-evaluated studies in the field of nursing [24], acupuncture [25], and diagnostic testing [26]. In the field of sports physical therapy, protocol registrations (38.3\%), risk of bias across studies (51.1\%), additional analysis (40.4\%), and funding $(21.3 \%)$ were the most problematic PRISMA items. Although the quality of SR and MA reporting in sports physical therapy was medium-to-low, similar to that in other clinical fields, key reporting components of the SR process were missing in most of the MAs and SRs. The critical appraisal of such studies must improve these reporting issues, which pertain to general MAs (27 items). For better EBP in sports physical therapy, authors and readers should examine assumptions in more detail, and report valid and adequate results. The PRISMA guidelines should be used more extensively to improve reporting practices in physical therapy.

Protocol registration is increasingly recommended in clinical trials [57] and SRs [34], but this study showed a low protocol enrollment of $38.3 \%$ (item 5). In a previous survey, only about one-fifth of SRs in physical therapy were registered, indicating that the enrollment rate was low [58]. According to the Cochrane Handbook for systematic literature review of interventions, the prospective registration of the protocol reduces the author's bias by publicly documenting a priori planned methodology [34,36]. Importantly, the registered SRs showed significantly higher methodological quality compared to the unregistered SRs. The protocol provides transparency and clarifies the hypothesis, methodology, and analysis of the SRs and MAs undertaken.

Quality assessment of meta-analysis for randomized controlled trials (RCT) was performed using the Risk of Bias tool developed by the Cochrane group [59]. The NRS tools for Newcastle and Ottawa Scale (NOS) [60], and Risk of Bias Assessment tool for Non-randomized Studies (ROBANS) [61]. However, there may be some confusion in the concepts of the reporting standards for individual studies (CONSORT statement) [62]. Strengthening the Reporting of Observational Studies in Epidemiology (STROBE) statement [63], and quality assessment tools for meta-analysis (ROB, NOBANS) [64].

One study reported the STROBE statement as a reporting standard for individual studies, as opposed to a quality assessment tool for meta-analysis [65]. The STROBE statement is a checklist of items that should be included in reports of cohort studies. An explanation and elaboration article discussed each checklist item and provided the methodological background and published examples of transparent reporting [63]. The reporting criterion for meta-analysis of observational studies should be evaluated as MOOSE [30].

For summary measures, the type of effect size measure used in the manuscript must be described. The OR and standardized mean difference (SMD) as summary measures were indicated in the studies (item 13). The effect size is a key concept in a meta-analysis, and an essential component of quantitative research reporting and hypothesis testing [40]. In many studies, a corrected SMD, i.e., Hedges' g with $95 \%$ CI was computed in consideration of the small sample size, and the inverse of the variance was used as the weight for each effect size [66]. As shown herein, studies need to classify the effect size computation, variance computation, and equations, and present them in an easily comprehensible manner for readers. However, only 5 of 47 studies described the effect size computation [29,65,67-69] (Supplementary Materials Table S1). One benefit of evaluating the effect size is that it quantifies the difference between groups in the observed data [70]. Moreover, the effect size is presented as a standard deviation; thus, it can be compared between studies and utilized in MAs, as well [71]. Researchers in the field of clinical medicine should also recognize the benefits of the effect size and use it widely in medical research.

Subgroup analyses further decrease the number of studies and thus weaken the power of the analysis, necessitating a careful interpretation of the data. Additionally, only 1 of the 23 studies performed a multivariate analysis [72].

The quality evaluation level of the 47 studies that were investigated revealed low to moderate and very low levels in statistical issues, such as mentioning the effect size formula 
and variance in the methods section. MAs use a summary measure with a statistically known variance [73], and the effect size variance formula is related to the distributional assumption such as the normality and homogeneity assumption for hypothesis testing. The results of effect size computation (like the SMD dealing with continuous variables, correlations, and odds ratios with dichotomous variables) should be provided for each individual MA study as major characteristics of the included studies $[27,40]$.

There were some flaws in the reviewed articles, and some suggestions were proposed for more valid MA results. Applying appropriate MA assessment tools for physical therapy research is required to increase the reviewed articles' validity. The synthesis of research studies in physical therapy research includes various study designs such as RCTs, observational studies, and scholars must consider the appropriate method of exploring validated reviews in physical therapy research.

As of 2021, version 6.0 of the Cochrane Handbook for Systematic Reviews of Interventions has been released [14]. The ROB 2 is the gold standard to evaluate the quality of RCT biases [39] and is a reorganized form of the Cochrane ROB tool by the same team [74]. The key features are that researchers can simply decide if a bias exists in the reviewed research and can evaluate bias for particular result findings within an RCT design and beyond the RCT design [75]. The Risk of Bias in Non-randomized Studies of Interventions (ROBINS-I) was also developed to evaluate intervention studies with nonrandomization in the Cochrane handbook (version 6.0). The main differences are that reviewers can easily critique the bias (using "low," "moderate," "serious," and "critical"), focusing on the after-intervention effects [76].

Researchers should use appropriate, updated quality assessment tools to reflect a study's research design and objectives and consider the complexity of interventions, proper groupings, and scientific effect size calculations. In addition, the present study proposed measures to improve the quality of MAs and ultimately aimed to examine the current situation, contributing to the enhancement of the EBP of sports physical therapy.

\subsection{Limitations}

To our knowledge, no study has investigated the reporting quality of SRs and MAs in the field of sports physical therapy. However, the present study has some limitations.

The database searches were only conducted in three specific journals based on their IF in the field of sports physical therapy. We need to comprehensively search the relevant databases related to sports physical therapy to conduct future SRs. For example, other journals from the field of sports and exercise medicine (e.g., British Journal of Sports Medicine) are important and should be included in the next study. We will extend the more studies to for 10 years in the next study.

The authors of the reviewed articles may have used the appropriate method but omitted important details from the report or removed key information during the publication process. We were in the position of the reader and could evaluate what was reported in the articles only. Additionally, there may be limitations in that the scope of the research may be different from the part where the actual research was conducted because the researcher reported based on the writing of a paper.

Quality thresholds were based on previous studies and were not agreed to be absolutely not interpreted. In addition, we determined that the quality of the performance was appropriate only if the reporting was adequate in terms of each checklist. If a comprehensive quality evaluation of the reporting criteria is conducted by including studies other than those in the top journals, the issue of low quality could be even more serious.

Because of research ethics, sports physical therapy studies need to perform general physical therapy in addition to the major intervention; thus, the lack of studies that only examined the physical therapy intervention poses a considerable limitation. In the future, when conducting systematic literature reviews and MAs, it will be helpful to improve the quality of clinical studies only when non-random studies, as well as RCT studies, are included due to the nature of clinical studies in physical therapy. 


\subsection{Clinical Implications}

The findings of our study suggest that physical therapy studies need to be designed appropriately as per the purpose of the study and that physical therapy programs for patients should be structured more systematically. Considering the lack of previous studies that qualitatively evaluate and emphasize clinical judgment, future studies need to discuss complex interventions and network MAs as recent research trends.

\section{Conclusions}

This critical assessment demonstrated that the current quality of reporting and conducting of MAs and SRs is low to moderate, as it is in other medical disciplines. Problem areas of current meta-analyses and SRs include the exploration of the risk of bias across studies, protocol registrations, and additional analyses. Performing a meta-analysis with inadequate reporting increases the risk of invalid results in a meta-analysis.

Therefore, a reporting guideline, such as the PRISMA statement, is helpful for authors when writing meta-analyses and SR.s Clinicians need to have a thorough knowledge of research methodology, to render the interpretation of sophisticated statistical analyses easier. In addition, the present study proposed measures to improve the quality of meta-analyses, and ultimately aimed to examine the current situation, contributing to the enhancement of the practice of sports physical therapy.

Supplementary Materials: The following are available online at https:/ /www.mdpi.com/article/10 .3390/healthcare9101368/s1, Table S1: Analysis of articles according to the PRISMA recommendations.

Author Contributions: Conceptualization, S.-H.C., and I.-S.S.; Methodology, I.-S.S.; Writing-Original Draft Preparation, S.-H.C.; Writing—Review \& Editing, S.-H.C., and I.-S.S.; Project Administration, I.S.S. All authors have read and agreed to the published version of the manuscript.

Funding: This research did not receive any specific grant from funding agencies in the public, commercial, or not-for-profit sectors.

Institutional Review Board Statement: This study was approved by the institutional review board (IRB) of Nambu University (ethical code: 1041478-2017-HR-016; approved date: 8 November 2017) and was conducted in accordance with the ethical standards of the Declaration of Helsinki.

Informed Consent Statement: Since this study analyzed existing research results, we received an expedited review with exemption from informed consent.

Data Availability Statement: All data relevant to the study are included in the article. Data were collected from studies published online or publicly available, and specific details related to the data will be made available upon request.

Conflicts of Interest: The authors declare that they have no conflicts of interest. 


\section{Appendix A}

Table A1. Study characteristics of included systematic review and meta-analysis in reporting quality assessment.

\begin{tabular}{|c|c|c|c|c|c|c|c|c|c|}
\hline \# & Author (Country*) & Year & Journal & Type & $\begin{array}{l}\text { The Number and } \\
\text { Design of Included } \\
\text { Studies }\end{array}$ & $\begin{array}{l}\text { Population/Patients/ } \\
\text { Defects }\end{array}$ & Intervention & $\begin{array}{l}\text { Comparison between } \\
\text { Interventions }\end{array}$ & Outcome \\
\hline 1 & Games et al. (USA) & 2015 & $\begin{array}{l}\text { J. Athl. } \\
\text { Train }\end{array}$ & MA & $\begin{array}{c}10 \text { studies } \\
\text { (10 clinical trials) }\end{array}$ & $\begin{array}{l}\text { Participants with healthy adults: } \\
\text { (1) Use of a commercially available WBV device } \\
\text { (2) a human research model } \\
\text { (3) a pre-WBV condition and at least } 1 \mathrm{WBV} \\
\text { experimental condition }\end{array}$ & $\begin{array}{l}\text { Therapeutic whole-body } \\
\text { vibration (WBV) }\end{array}$ & $\begin{array}{l}\text { Vibration type and } \\
\text { frequency }\end{array}$ & $\begin{array}{l}\text { - Muscle-oxygenation levels } \\
\text { Peripheral blood flow }\end{array}$ \\
\hline 2 & $\begin{array}{l}\text { Sciascia et al. } \\
\text { (USA) }\end{array}$ & 2015 & $\begin{array}{l}\text { J. Athl. } \\
\text { Train }\end{array}$ & SR & $\begin{array}{l}11 \text { studies } \\
\text { (11 Case series reports) }\end{array}$ & $\begin{array}{l}\text { (1) Surgical repair of an isolated superior labral } \\
\text { injury of a superior labral injury with soft tissue } \\
\text { debridement } \\
\text { (2) Overhead athletes equal to or less than } 40 \\
\text { years of age }\end{array}$ & $\begin{array}{l}\text { Return to } \\
\text { preinjury levels of participation }\end{array}$ & $\mathrm{NA}$ & $\begin{array}{l}\text { - Return-to-participation odds and } \\
\text { interpretations for athletes with } \\
\text { isolated superior labral repair } \\
\text { Return-to-participation odds and } \\
\text { interpretations for athletes with } \\
\text { concurrent superior labral repair and } \\
\text { soft tissue }\end{array}$ \\
\hline 3 & $\begin{array}{l}\text { Knapik \& Steelman } \\
\text { (USA) }\end{array}$ & 2016 & $\begin{array}{l}\text { J. Athl. } \\
\text { Train }\end{array}$ & MA & $\begin{array}{l}15 \text { studies ( } 15 \\
\text { Retrospective studies) }\end{array}$ & $\begin{array}{l}\text { Injuries during military static-line } \\
\text { airborne operations }\end{array}$ & Risk factors for injury & One group & $\begin{array}{l}\text { Risk ratio } \\
\text { Odds ratio } \\
\text { (Summary } 95 \% \\
\text { confidence interval) }\end{array}$ \\
\hline 4 & $\begin{array}{l}\text { Powden et al. } \\
\text { (USA) }\end{array}$ & 2017 & $\begin{array}{l}\text { J. Athl. } \\
\text { Train }\end{array}$ & MA & $\begin{array}{l}15 \text { studies } \\
\text { (10 RCTs and } 5 \text { non-RCTs } \\
\text { design) }\end{array}$ & Individuals with chronic ankle instability & $\begin{array}{l}\text { Balance Training, } \\
\text { Manual Therapy, } \\
\text { Combined Interventions }\end{array}$ & $\begin{array}{l}\text { One group or control } \\
\text { group }\end{array}$ & $\begin{array}{l}\text { Improving health-related } \\
\text { quality of life (HRQL) }\end{array}$ \\
\hline 5 & $\begin{array}{l}\text { Alsalaheen et al. } \\
\text { (USA) }\end{array}$ & 2017 & $\begin{array}{l}\text { J. Athl. } \\
\text { Train }\end{array}$ & MA & $\begin{array}{l}17 \text { studies }(17 \\
\text { observational studies) }\end{array}$ & $\begin{array}{l}\text { (1) A total of } 1777 \text { patients ( } 1250 \text { males, } \\
527 \text { females) } \\
\text { with concussion } \\
\text { (2) Participants from } 13 \text { to } 33 \text { years old } \\
\text { representing clinical management of concussion } \\
\text { (3) Participants in the reviewed studies } \\
\text { included middle and high school-aged children, } \\
\text { college-aged adults, and professional athletes }\end{array}$ & $\begin{array}{l}\text { Computerized neurocognitive } \\
\text { test and self-reported symptoms }\end{array}$ & $\begin{array}{l}\text { Participants with } \\
\text { self-reported symptoms } \\
\text { before } 1 \text { week and } \\
\text { between } 1 \text { and } 3 \text { weeks } \\
\text { postconcussion. }\end{array}$ & $\begin{array}{l}\text { - Verbal memory } \\
\text { Visual memory } \\
\text { Processing speed } \\
\text { Reaction time } \\
\text { with } 1 \text { week wossion symptom scale } \\
\text { itconcussion }\end{array}$ \\
\hline 6 & Slater et al. (USA) & 2017 & $\begin{array}{l}\text { J. Athl. } \\
\text { Train }\end{array}$ & MA & $\begin{array}{l}27 \text { studies }(27 \text { clinical } \\
\text { trials })\end{array}$ & $\begin{array}{l}\text { Anterior cruciate } \\
\text { ligament reconstruction (ACLR), } \\
\text { anterior cruciate ligament deficient (ACLD) }\end{array}$ & $\begin{array}{l}\text { 3-dimensional (3D) lower } \\
\text { extremity kinematics and } \\
\text { kinetics of walking among } \\
\text { individuals }\end{array}$ & $\begin{array}{l}\text { Healthy control } \\
\text { participants }\end{array}$ & $\begin{array}{l}\text { - Peak external knee-flexion } \\
\text { moment, knee-extension moment } \\
\text { : Peak knee-flexion angle } \\
\text { : Peak hip-flexion angle } \\
\text { : Peak knee-adduction angle } \\
\text { moak external knee-adduction } \\
\text { moment }\end{array}$ \\
\hline 7 & Armitano et al. (USA) & 2018 & $\begin{array}{l}\text { J. Athl. } \\
\text { Train }\end{array}$ & SR & $\begin{array}{c}18 \text { studies } \\
\text { (18 clinical trials) }\end{array}$ & Healthy adults (age $>18$ years) & $\begin{array}{l}\text { The use of augmented } \\
\text { information for reducing } \\
\text { anterior cruciate ligament injury } \\
\text { risk during jump landings }\end{array}$ & $\begin{array}{l}\text { Control group or no } \\
\text { control group }\end{array}$ & $\begin{array}{l}\text { Kinematic and kinetic risk factors } \\
\text { associated with anterior cruciate } \\
\text { ligament injury due to jump landing } \\
\text { technique }\end{array}$ \\
\hline
\end{tabular}


Table A1. Cont.

\begin{tabular}{|c|c|c|c|c|c|c|c|c|c|}
\hline \# & Author (Country*) & Year & Journal & Type & $\begin{array}{c}\text { The Number and } \\
\text { Design of Included } \\
\text { Studies }\end{array}$ & $\begin{array}{l}\text { Population/Patients/ } \\
\text { Defects }\end{array}$ & Intervention & $\begin{array}{c}\text { Comparison between } \\
\text { Interventions }\end{array}$ & Outcome \\
\hline 8 & Bullock et al. (USA) & 2018 & $\begin{array}{l}\text { J. Athl. } \\
\text { Train }\end{array}$ & MA & $\begin{array}{l}6 \text { studies } \\
\text { (6 prospective studies) }\end{array}$ & Baseball players aged 13 years or older & $\begin{array}{l}\text { The relationship between } \\
\text { shoulder ROM and the risk of } \\
\text { arm injuries }\end{array}$ & $\begin{array}{l}\text { Uninjured participant or } \\
\text { previously determined } \\
\text { injured cut points }\end{array}$ & $\begin{array}{l}\text { Pooled proportion for absolute } \\
\text { shoulder range of motion. } \\
\text { : Internal rotation } \\
\text { : Toternal rotation } \\
\text { - Horizonge of motion } \\
\text { Hadduction }\end{array}$ \\
\hline 9 & Takeno et al. (USA) & 2019 & $\begin{array}{l}\text { J. Athl. } \\
\text { Train }\end{array}$ & MA & $\begin{array}{c}7 \text { studies } \\
\text { (4 RCTs and 2 } \\
\text { Quasi-experimental } \\
\text { studies and Case-control } \\
\text { studies) }\end{array}$ & Patients with Subacromial Impingement & $\begin{array}{l}\text { The short- and long-term } \\
\text { therapeutic } \\
\text { interventions for SIS }\end{array}$ & $\begin{array}{l}\text { Control group or No } \\
\text { control group }\end{array}$ & $\begin{array}{l}\text { - Scapular upward rotation } \\
\text { - Scapular posterior tilt } \\
\text { Scapular internal rotation } \\
\text { and hand score }\end{array}$ \\
\hline 10 & $\begin{array}{l}\text { Vallandingham } \\
\text { et al. (USA) }\end{array}$ & 2019 & $\begin{array}{l}\text { J. Athl. } \\
\text { Train }\end{array}$ & MA & 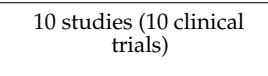 & Individuals with chronic ankle instability & Joint mobilizations & $\underset{\text { group }}{\text { Control group or sham }}$ & $\begin{array}{l}\text { - Dorsiflexion range of motion } \\
\text { Dynamic postural control }\end{array}$ \\
\hline 11 & $\begin{array}{c}\text { Jeong et al. } \\
\text { (Republic of Korea) }\end{array}$ & 2019 & $\begin{array}{l}\text { J. Athl. } \\
\text { Train }\end{array}$ & MA & $\begin{array}{l}7 \text { studies } \\
(7 \mathrm{RCTs})\end{array}$ & $\begin{array}{l}\text { Patients with Knee Osteoarthritis } \\
\text { (age > } 50 \text { years) }\end{array}$ & Proprioceptive training & Control group & $\begin{array}{l}\text { - Pain } \\
\text { Stiffness } \\
\text { outcome } \\
\text { o Physical function questionnaire } \\
\text { Phynction test }\end{array}$ \\
\hline 12 & $\begin{array}{l}\text { Montalvo et al. } \\
\text { (USA) }\end{array}$ & 2019 & $\begin{array}{l}\text { J. Athl. } \\
\text { Train }\end{array}$ & MA & $\begin{array}{l}36 \text { studies } \\
\text { (Observational Cohort } \\
\text { and Cross-Sectional } \\
\text { Studies) }\end{array}$ & $\begin{array}{l}\text { Studies were included if they provided the } \\
\text { number of ACL injuries and the number of } \\
\text { athlete-exposures (AEs) } \\
\text { by sex or enough information to allow the } \\
\text { number of ACL injuries by sex to be calculated. }\end{array}$ & $\begin{array}{l}\text { Injury incidence by sex and } \\
\text { sport classification }\end{array}$ & NA & $\begin{array}{l}\text { Sex differences in incidence rates } \\
\text { (IRs) of anterior cruciate ligament } \\
\text { (ACL) injury by sport type } \\
\text { (collision, contact, limited contact, } \\
\text { and noncontact) }\end{array}$ \\
\hline 14 & $\begin{array}{l}\text { McAuliffe et al. } \\
\text { (United Kingdom) }\end{array}$ & 2019 & $\begin{array}{l}\text { J. Athl. } \\
\text { Train }\end{array}$ & MA & $\begin{array}{l}19 \text { studies } \\
\text { (cross-sectional or } \\
\text { baseline data } \\
\text { from prospective or } \\
\text { intervention studies) }\end{array}$ & Individuals with Achilles tendinopathy (AT) & $\begin{array}{l}\text { - Maximal-strength profile } \\
\text { - Explosive-strength Profile } \\
\text { (Hoactive-strength profile } \\
\text { Hopping) }\end{array}$ & $\begin{array}{l}\text { Healthy control } \\
\text { participants }\end{array}$ & Plantar flexion (PF) strength \\
\hline 15 & $\begin{array}{l}\text { Kang et al. } \\
\text { (Taiwan) }\end{array}$ & 2019 & $\begin{array}{l}\text { J. Athl. } \\
\text { Train }\end{array}$ & MA & $\begin{array}{c}18 \text { studies } \\
\text { (7 systematic reviews } \\
\text { and } 11 \text { meta-analyses) }\end{array}$ & Healthy adults & Push-up plus exercise & $\begin{array}{l}\text { Different hand positions } \\
\text { (the distance between } \\
\text { the hands, } \\
\text { shoulder-flexion angle, } \\
\text { and elbow-flexion angle) } \\
\text { and different lower } \\
\text { extremity positions } \\
\text { variably }\end{array}$ & $\begin{array}{l}\text { Serratus anterior and upper trapeziu } \\
\text { electromyographic analysis }\end{array}$ \\
\hline 16 & $\begin{array}{l}\text { Desjardins- } \\
\text { Charbonneau et al. } \\
\text { (Canada) }\end{array}$ & 2015 & $\begin{array}{l}\text { J. Orthop. } \\
\text { Sports Phys. } \\
\text { Ther. }\end{array}$ & MA & $\begin{array}{l}21 \text { studies } \\
\text { (21 RCTs) }\end{array}$ & Patients with rotator cuff $(\mathrm{RC})$ tendinopathy & Manual therapy (MT) & $\begin{array}{l}\text { Placebo or in addition to } \\
\text { another intervention or a } \\
\text { multimodal intervention }\end{array}$ & - Pain \\
\hline
\end{tabular}


Table A1. Cont.

\begin{tabular}{|c|c|c|c|c|c|c|c|c|c|}
\hline \# & Author (Country*) & Year & Journal & Type & $\begin{array}{l}\text { The Number and } \\
\text { Design of Included } \\
\text { Studies }\end{array}$ & $\begin{array}{l}\text { Population/Patients/ } \\
\text { Defects }\end{array}$ & Intervention & $\begin{array}{c}\text { Comparison between } \\
\text { Interventions }\end{array}$ & Outcome \\
\hline 17 & $\underset{\text { (Brazil) }}{\text { Almeida et al. }}$ & 2015 & $\begin{array}{l}\text { J. Orthop. } \\
\text { Sports Phys. } \\
\text { Ther. }\end{array}$ & MA & $\begin{array}{l}16 \text { Studies } \\
\text { (cross-sectional, } \\
\text { case-control, prospective, } \\
\text { and retrospective study) }\end{array}$ & Runners at least 18 years of age & $\begin{array}{l}\text { Biomechanical characteristics } \\
\text { of foot-strike patterns during } \\
\text { running }\end{array}$ & $\begin{array}{l}\text { Rearfoot strike and } \\
\text { forefoot strike or midfoot } \\
\text { in shod conditions }\end{array}$ & $\begin{array}{l}\text { - Vertical ground reaction force: } \\
\text { Second peak } \\
\text { - Vertical loading rate } \\
\text { - Ankle plantar flexion moment }\end{array}$ \\
\hline 18 & $\begin{array}{l}\text { Deasy et al. } \\
\text { (Australia) }\end{array}$ & 2016 & $\begin{array}{l}\text { J. Orthop. } \\
\text { Sports Phys. } \\
\text { Ther. }\end{array}$ & MA & $\begin{array}{l}5 \text { studies } \\
\text { (4 Case-control studies } \\
\text { and } 1 \text { two-group } \\
\text { pre-post design }\end{array}$ & People with symptomatic knee osteoarthritis & $\begin{array}{l}\text { A modified grading of } \\
\text { recommendations assessment, } \\
\text { development and evaluation } \\
\text { approach }\end{array}$ & $\begin{array}{l}\text { Healthy control } \\
\text { participants }\end{array}$ & $\begin{array}{l}\text { - Isometric hip muscle strength } \\
\text { - Isokinetic hip muscle strength }\end{array}$ \\
\hline 19 & $\begin{array}{l}\text { Gattie et al. } \\
\text { (USA) }\end{array}$ & 2017 & $\begin{array}{l}\text { J. Orthop. } \\
\text { Sports Phys. } \\
\text { Ther. }\end{array}$ & MA & $\begin{array}{l}13 \text { studies } \\
\text { (13 RCTs) }\end{array}$ & $\begin{array}{l}\text { Human subjects who had musculoskeletal } \\
\text { conditions }\end{array}$ & $\begin{array}{l}\text { Dry needling dry needling } \\
\text { performed } \\
\text { by a physical therapist }\end{array}$ & $\begin{array}{l}\text { Control or other } \\
\text { intervention }\end{array}$ & $\begin{array}{ll}\text { - Pain } & \text { Pressure pain threshold(PPT) } \\
\text { - } & \text { Functional outcome }\end{array}$ \\
\hline 20 & $\begin{array}{l}\text { Zhao et al. } \\
\text { (China) }\end{array}$ & 2017 & $\begin{array}{l}\text { J. Orthop. } \\
\text { Sports Phys. } \\
\text { Ther. }\end{array}$ & MA & $\begin{array}{l}11 \text { studies } \\
\text { (11 RCTs) }\end{array}$ & Postmenopausal women & Combined exercise interventions & $\begin{array}{c}\text { Control group } \\
\text { (nonexercise group) }\end{array}$ & $\begin{array}{l}\text { Lumbar spine, femoral neck, } \\
\text { total hip, and total body BMD } \\
\text { (bone mineral density) }\end{array}$ \\
\hline 21 & $\begin{array}{l}\text { Basson et al. } \\
\text { (South Africa) }\end{array}$ & 2017 & $\begin{array}{l}\text { J. Orthop. } \\
\text { Sports Phys. } \\
\text { Ther. }\end{array}$ & MA & $\begin{array}{l}19 \text { studies } \\
\text { (19 RCTs) }\end{array}$ & $\begin{array}{l}\text { Participants over the age of } 18 \text { years with } \\
\text { neuromusculoskeletal conditions indicative of } \\
\text { neural tissue dysfunction }\end{array}$ & $\begin{array}{l}\text { Neural Mobilization for } \\
\text { Neuromusculoskeletal } \\
\text { Conditions }\end{array}$ & Control group & $\begin{array}{l}\text { - Pain and disability in N-LBP } \\
\text { (nerve-related low back pain) and } \\
\text { (nerve-related neck and arm pain) } \\
\text { (nerved } \\
\text { tunnain and disability in CTS(carpal } \\
\text { tundrome) }\end{array}$ \\
\hline 22 & $\begin{array}{l}\text { Nascimento } \\
\text { et al. } \\
\text { (Brazil) }\end{array}$ & 2018 & $\begin{array}{l}\text { J. Orthop. } \\
\text { Sports Phys. } \\
\text { Ther. }\end{array}$ & MA & $\begin{array}{l}14 \text { studies } \\
\text { (Randomized and/or } \\
\text { controlled trials) }\end{array}$ & Individuals with patellofemoral pain & $\begin{array}{l}\text { Experimental intervention is } \\
\text { strengthening, } \\
\text { in order to increase strength of } \\
\text { the posterolateral hip muscles }\end{array}$ & $\begin{array}{c}\text { Nothing/placebo or } \\
\text { knee strengthening alone }\end{array}$ & $\begin{array}{l}\text { Measures of strength, } \\
\text { pain intensity, or activity }\end{array}$ \\
\hline 23 & $\underset{\text { (USA) }}{\text { Eckenrode et al. }}$ & 2018 & $\begin{array}{l}\text { J. Orthop. } \\
\text { Sports Phys. } \\
\text { Ther. }\end{array}$ & MA & $\begin{array}{l}9 \text { studies } \\
\text { (9 RCTs) }\end{array}$ & Individuals with patellofemoral pain & $\begin{array}{l}\text { Manual therapy or manual } \\
\text { therapy plus exercise }\end{array}$ & $\begin{array}{l}\text { Sham/Control or } \\
\text { alternative treatment }\end{array}$ & Pain and self-reported function \\
\hline 24 & $\begin{array}{l}\text { Al-Mahrouqi et al. } \\
\text { (Australia) }\end{array}$ & 2018 & $\begin{array}{l}\text { J. Orthop. } \\
\text { Sports Phys. } \\
\text { Ther. }\end{array}$ & MA & $\begin{array}{l}8 \text { studies } \\
\text { (8 clinical trials) }\end{array}$ & Adults with ankle osteoarthritis & Physical impairments & $\begin{array}{l}\text { Healthy controls or } \\
\text { the unaffected ankle }\end{array}$ & $\begin{array}{l}\text { Range of motion, ankle arthrometry, } \\
\text { calf cross-sectional area (CSA) } \\
\text { and fatty infiltration, joint torque, } \\
\text { muscle electromyography (EMG), } \\
\text { standing balance, body impairment }\end{array}$ \\
\hline 25 & $\begin{array}{l}\text { Lam et al. } \\
\text { (Canada) }\end{array}$ & 2018 & $\begin{array}{l}\text { J. Orthop. } \\
\text { Sports Phys. } \\
\text { Ther. }\end{array}$ & MA & $\begin{array}{l}12 \text { studies } \\
\text { (12 RCTs) }\end{array}$ & $\begin{array}{l}\text { Patients with either acute (less than } 12 \text { weeks in } \\
\text { duration) or chronic (greater than } 12 \text { weeks in } \\
\text { duration) low back pain (LBP) }\end{array}$ & $\begin{array}{l}\text { McKenzie method of mechanical } \\
\text { diagnosis and therapy (MDT) }\end{array}$ & $\begin{array}{l}\text { Other interventions in } \\
\text { patients with acute or } \\
\text { chronic LBP }\end{array}$ & Pain and disability \\
\hline 26 & $\begin{array}{l}\text { Perriman et al. } \\
\text { (Australia) }\end{array}$ & 2018 & $\begin{array}{l}\text { J. Orthop. } \\
\text { Sports Phys. } \\
\text { Ther. }\end{array}$ & MA & $\begin{array}{l}10 \text { studies } \\
(10 \text { RCTs })\end{array}$ & $\begin{array}{l}\text { Participants who had } \\
\text { Anterior Cruciate Ligament } \\
\text { Reconstruction (ACSR) }\end{array}$ & $\begin{array}{l}\text { Open- Kinetic-Chain (OKC) } \\
\text { quadriceps exercises }\end{array}$ & $\begin{array}{l}\text { Closed-Kinetic-Chain } \\
\text { (CKC) } \\
\text { quadriceps exercises }\end{array}$ & $\begin{array}{l}\text { Anterior tibial laxity, lower-limb } \\
\text { strength, function, quality of life, or } \\
\text { adverse events in the ACLR } \\
\text { population }\end{array}$ \\
\hline
\end{tabular}


Table A1. Cont.

\begin{tabular}{|c|c|c|c|c|c|c|c|c|c|}
\hline \# & Author (Country*) & Year & Journal & Type & $\begin{array}{l}\text { The Number and } \\
\text { Design of Included } \\
\text { Studies }\end{array}$ & $\begin{array}{l}\text { Population/Patients/ } \\
\text { Defects }\end{array}$ & Intervention & $\begin{array}{l}\text { Comparison between } \\
\text { Interventions }\end{array}$ & Outcome \\
\hline 27 & $\underset{\text { (USA) }}{\text { Mansfield et al. }}$ & 2019 & $\begin{array}{l}\text { J. Orthop. } \\
\text { Sports Phys. } \\
\text { Ther. }\end{array}$ & MA & $\begin{array}{l}21 \text { studies } \\
\text { (21 RCTs) }\end{array}$ & $\begin{array}{l}\text { Individuals who received any form of needling } \\
\text { therapy to their muscle(s), including } \\
\text { healthy/uninjured, injured, } \\
\text { nonoperative, and operative. }\end{array}$ & $\begin{array}{l}\text { Any form of needling therapy } \\
\text { provided to a muscle, } \\
\text { irrespective of body region. }\end{array}$ & $\begin{array}{l}\text { Any intervention such as } \\
\text { therapeutic exercise, } \\
\text { modality, or form } \\
\text { of placebo needling } \\
\end{array}$ & $\begin{array}{l}\text { Any formal assessment of muscle } \\
\text { force production }\end{array}$ \\
\hline 28 & $\begin{array}{l}\text { den Bandt et al. } \\
\text { (Netherlands) }\end{array}$ & 2019 & $\begin{array}{l}\text { J. Orthop. } \\
\text { Sports Phys. } \\
\text { Ther. }\end{array}$ & MA & $\begin{array}{c}24 \text { studies } \\
\text { (15 Cross-sectional } \\
\text { studies, } \\
5 \text { Case-control studies, } \\
1 \text { Clinical trial, } \\
1 \text { Cohort study, } \\
1 \text { Longitudinal treatment } \\
\text { study, } \\
1 \text { Observational study) }\end{array}$ & $\begin{array}{l}\text { People with nonspecific } \\
\text { low back pain }\end{array}$ & $\begin{array}{l}\text { Pain mechanisms in low back } \\
\text { pain }\end{array}$ & Health controls & $\begin{array}{l}\text { Mechanical quantitative } \\
\text { sensory testing outcomes } \\
\text { - Pressure pain thresholds (PPTs) } \\
\text { - Temporal summation } \\
\text { - Conditioned pain modulation }\end{array}$ \\
\hline 29 & $\begin{array}{l}\text { Desmeules et al. } \\
\text { (Canada) }\end{array}$ & 2015 & $\begin{array}{l}\text { Phys. Ther. } \\
\text { Sports }\end{array}$ & MA & $\begin{array}{l}11 \text { studies } \\
\text { (11 RCTs) }\end{array}$ & $\begin{array}{l}\text { Adults suffering } \\
\text { from RC tendinopathy }\end{array}$ & Therapeutic ultrasound (US) & $\begin{array}{l}\text { Placebo or other } \\
\text { interventions in } \\
\text { adults suffering from RC } \\
\text { tendinopathy }\end{array}$ & $\begin{array}{l}\text { - Pain reduction } \\
\text { - Functional improvement }\end{array}$ \\
\hline 30 & $\begin{array}{l}\text { Sales et al. } \\
\text { (Brazil) }\end{array}$ & 2016 & $\begin{array}{l}\text { Phys. Ther. } \\
\text { Sports }\end{array}$ & MA & $\begin{array}{l}20 \text { studies } \\
\text { (20 RCTs) }\end{array}$ & Athletes & $\begin{array}{l}\text { Respiratory muscle training } \\
\text { (RMT) }\end{array}$ & non-athletes & Respiratory muscle endurance (RME \\
\hline 31 & $\begin{array}{l}\text { Tsikopoulos et al. } \\
\text { (Greece) }\end{array}$ & 2016 & $\begin{array}{l}\text { Phys. Ther. } \\
\text { Sports }\end{array}$ & MA & $\begin{array}{l}5 \text { studies } \\
\text { (5 RCTs) }\end{array}$ & Adults with tendinopathy & Platelet-rich plasma injections & $\begin{array}{l}\text { Placebo or dry needling } \\
\text { injections }\end{array}$ & $\begin{array}{l}\text { Pain intensity } \\
\text { functional disability }\end{array}$ \\
\hline 32 & $\begin{array}{l}\text { Chou et al. } \\
\text { (Taiwan) }\end{array}$ & 2016 & $\begin{array}{l}\text { Phys. Ther. } \\
\text { Sports }\end{array}$ & MA & $\begin{array}{l}9 \text { studies } \\
(9 \mathrm{RCTs})\end{array}$ & Patients with lateral epicondylosis & $\begin{array}{l}\text { Autologous blood injection } \\
\text { in treating lateral epicondylosis }\end{array}$ & $\begin{array}{c}\text { corticosteroid injection } \\
\text { or } \\
\text { platelet-rich plasma } \\
\text { injection }\end{array}$ & $\begin{array}{l}\text { Pain related measurement in each } \\
\text { selected randomized controlled trial }\end{array}$ \\
\hline 33 & $\begin{array}{l}\text { Takasaki et al. } \\
\text { (Japan) }\end{array}$ & 2016 & $\begin{array}{l}\text { Phys. Ther. } \\
\text { Sports }\end{array}$ & MA & $\begin{array}{l}12 \text { studies } \\
\text { (9 Quasi-experimental, } \\
2 \text { Randomized } \\
\text { experimental } \\
1 \text { Randomized } \\
\text { cross-over) }\end{array}$ & Patients with shoulder pathologies & $\begin{array}{l}\text { Fatiguing task for the shoulder } \\
\text { musculature }\end{array}$ & $\begin{array}{c}\text { Glenohumeral } \\
\text { movements and } \\
\text { scapulothoracic resting } \\
\text { alignments }\end{array}$ & $\begin{array}{l}\text { Active repositioning acuity and } \\
\text { scapulothoracic resting alignment }\end{array}$ \\
\hline 34 & $\begin{array}{l}\text { Tsikopoulos et al. } \\
\text { (Greece) }\end{array}$ & 2016 & $\begin{array}{l}\text { Phys. Ther. } \\
\text { Sports }\end{array}$ & MA & $\begin{array}{l}9 \text { studies } \\
\text { (9 RCTs) }\end{array}$ & $\begin{array}{l}\text { Patients with epicondylopathy } \\
\text { and plantar fasciopathy }\end{array}$ & Autologous whole blood & Corticosteroid injections & $\begin{array}{l}\text { Assessment of pain relief assessment } \\
\text { of composite outcomes }\end{array}$ \\
\hline 35 & $\begin{array}{l}\text { Gomes-Neto et al. } \\
\text { (Brazil) }\end{array}$ & 2017 & $\begin{array}{l}\text { Phys. Ther. } \\
\text { Sports }\end{array}$ & MA & $\begin{array}{l}11 \text { studies } \\
\text { (11 RCTs) }\end{array}$ & $\begin{array}{l}\text { Patients } \\
\text { with low back pain }\end{array}$ & Stabilization exercise & $\begin{array}{l}\text { General exercises or } \\
\text { manual } \\
\text { therapy }\end{array}$ & Pain, disability, and function \\
\hline 36 & $\begin{array}{l}\text { Ghai et al. } \\
\text { (Germany) }\end{array}$ & 2017 & $\begin{array}{l}\text { Phys. Ther. } \\
\text { Sports }\end{array}$ & MA & $\begin{array}{c}50 \text { studies } \\
\text { (6 RCTs, } 42 \mathrm{CCTs}, \\
2 \text { observational } \\
\text { neuroimaging studies) }\end{array}$ & $\begin{array}{l}\text { Participants affected } \\
\text { by ankle instability }\end{array}$ & Joint stabilizers & Control group & $\begin{array}{l}\text { Proprioception, postural stability, } \\
\text { and neurological activity }\end{array}$ \\
\hline 37 & $\begin{array}{l}\text { Nae et al. } \\
\text { (Sweden) }\end{array}$ & 2017 & $\begin{array}{l}\text { Phys. Ther. } \\
\text { Sports }\end{array}$ & MA & $\begin{array}{l}28 \text { studies } \\
\text { (28 clinical trials) }\end{array}$ & $\begin{array}{l}\text { In participants with or without lower extremity } \\
\text { musculoskeletal disorders }\end{array}$ & $\begin{array}{l}\text { The performance of } \\
\text { weight-bearing functional tasks }\end{array}$ & 2D and 3D kinematics & $\begin{array}{l}\text { Measurement properties of visual } \\
\text { assessment and rating of Postural } \\
\text { Orientation Errors (POEs) }\end{array}$ \\
\hline
\end{tabular}


Table A1. Cont.

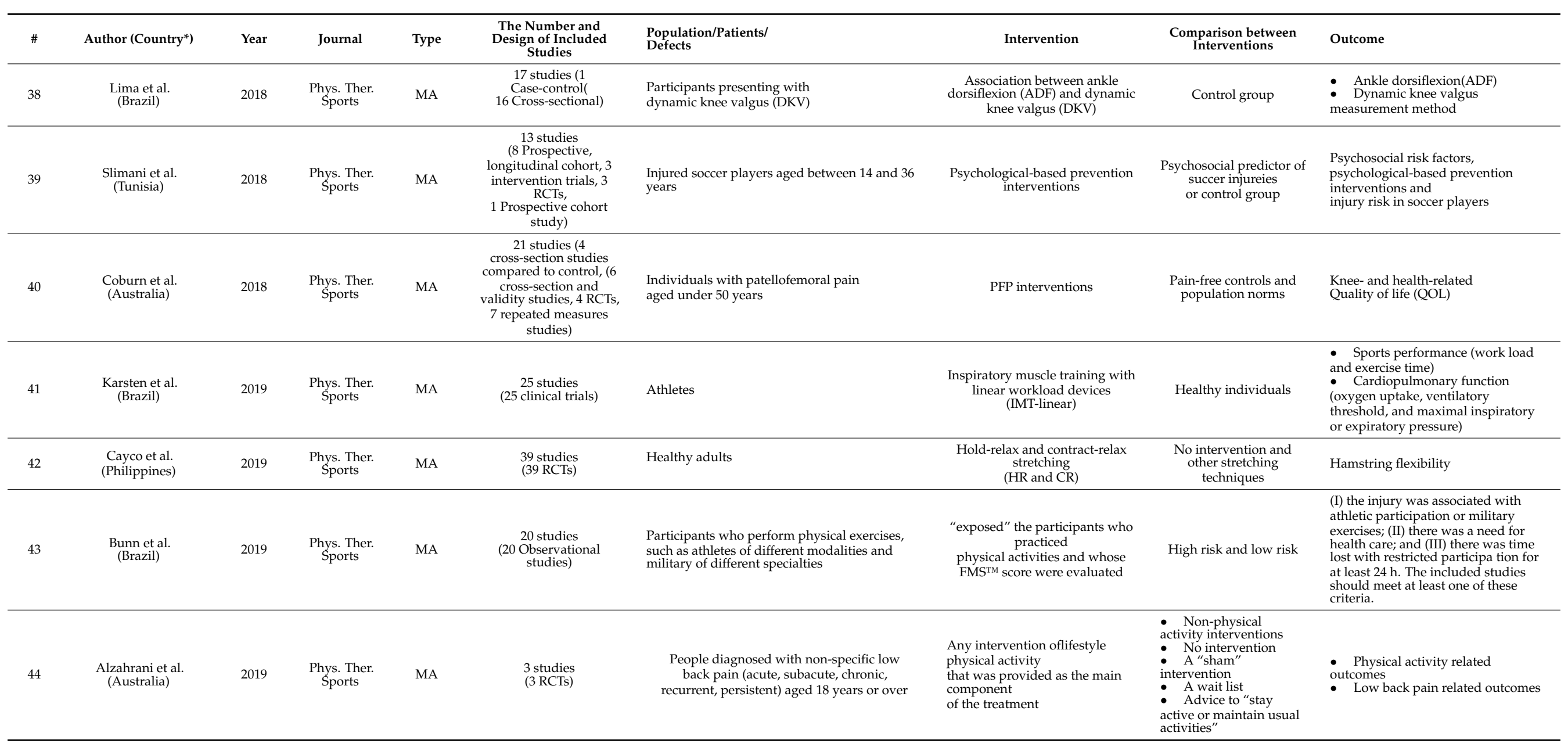


Table A1. Cont.

\begin{tabular}{|c|c|c|c|c|c|c|c|c|c|}
\hline \# & Author (Country*) & Year & Journal & Type & $\begin{array}{c}\text { The Number and } \\
\text { Design of Included } \\
\text { Studies }\end{array}$ & $\begin{array}{l}\text { Population/Patients/ } \\
\text { Defects }\end{array}$ & Intervention & $\begin{array}{l}\text { Comparison between } \\
\text { Interventions }\end{array}$ & Outcome \\
\hline 45 & $\begin{array}{l}\text { Dix et al. } \\
\text { (Australia) }\end{array}$ & 2019 & $\begin{array}{l}\text { Phys. Ther. } \\
\text { Sports }\end{array}$ & MA & $\begin{array}{c}16 \text { studies } \\
\text { (6 Cohort, } 5 \\
\text { Cross-sectional } \\
\text { laboratory studies, } \\
2 \text { Observational } \\
\text { prospective, } \\
\text { 2 Exploratory, } \\
1 \text { Correlation study) }\end{array}$ & asymptomatic females over 18 years old & $\begin{array}{l}\text { Relationship between hip } \\
\text { strength } \\
\text { and dynamic lower extremity } \\
\text { valgus, } \\
\text { Relationship between hip } \\
\text { strength and dynamic } \\
\text { lower extremity valgus for the } \\
\text { various tasks }\end{array}$ & $\begin{array}{l}\text { Validity of comparison } \\
\text { between the findings of } \\
\text { research that uses } \\
\text { different kinematic } \\
\text { assessment tasks }\end{array}$ & $\begin{array}{l}\text { - Strength measure (Hand held } \\
\text { dynamometry \& isometric testing } \\
\text { unless otherwise stated) } \\
\text { - Kinematic measure }\end{array}$ \\
\hline 46 & $\begin{array}{l}\text { Neilson et al. } \\
\text { (New Zealand) }\end{array}$ & 2019 & $\begin{array}{l}\text { Phys. Ther. } \\
\text { Sports }\end{array}$ & MA & $\begin{array}{c}11 \text { studies } \\
\text { (Randomized control } \\
\text { trials and } \\
\text { Clinically controlled } \\
\text { trials) }\end{array}$ & $\begin{array}{l}\text { - Neurologically and physically healthy } \\
\text { Man and woman } \\
\text { old Adolescents and adults aged } 12-65 \text { years }\end{array}$ & $\begin{array}{l}\text { Augmented Feedback (AF): } \\
\text { external or } \\
\text { extrinsic feedback given during } \\
\text { practice }\end{array}$ & $\begin{array}{c}\text { RCTs \& CCTs: changes } \\
\text { in key } \\
\text { landing biomechanical } \\
\text { parameters } \\
\text { in the AF groups } \\
\text { compared to control } \\
\text { groups without AF }\end{array}$ & $\begin{array}{l}\text { Numerical kinematic and kinetic } \\
\text { parameters reported }\end{array}$ \\
\hline 47 & $\begin{array}{l}\text { López et al. } \\
\text { (Spain) }\end{array}$ & 2019 & $\begin{array}{l}\text { Phys. Ther. } \\
\text { Sports }\end{array}$ & MA & $\begin{array}{c}6 \text { studies } \\
\text { (1 experimental trial, } \\
2 \text { randomized } \\
\text { experimental trials, } 1 \\
\text { randomized } \\
\text { double-blinded } \\
\text { controlled trial, } 1 \\
\text { randomized } \\
\text { assessor-blind, } \\
\text { placebo-controlled trial, } \\
1 \text { three-arm } \\
\text { assessor-blinded } \\
\text { randomized controlled } \\
\text { trial) }\end{array}$ & Participants aged over 18 years & Neurodynamic treatment & $\begin{array}{l}\text { No treatment, placebo, } \\
\text { and with other manual } \\
\text { therapy techniques }\end{array}$ & Hamstring flexibility \\
\hline
\end{tabular}

\section{Appendix B}

Table A2. Reporting key components of the systematic review process and meta-analyses by PRISMA guideline.

\begin{tabular}{|c|c|c|c|}
\hline Section/Topic & $\#$ & Checklist Item-Yes if Reported & No $(\%)$ of Reports $(n=47)$ \\
\hline \multicolumn{4}{|l|}{ Title } \\
\hline Title & 1 & Identify the report as a systematic review, meta-analysis, or both. & $47(100 \%)$ \\
\hline \multicolumn{4}{|l|}{ Abstract } \\
\hline Structured summary & 2 & $\begin{array}{l}\text { Provide a structured summary including, as applicable: background; objectives; data sources; study eligibility } \\
\text { criteria, participants, and interventions; study appraisal and synthesis methods; results; limitations; } \\
\text { conclusions and implications of key findings; systematic review registration number. }\end{array}$ & $10(21.3 \%)$ \\
\hline
\end{tabular}


Table A2. Cont.

\begin{tabular}{|c|c|c|c|}
\hline Section/Topic & $\#$ & Checklist Item-Yes if Reported & No $(\%)$ of Reports $(n=47)$ \\
\hline \multicolumn{4}{|l|}{ Introduction } \\
\hline Rationale & 3 & Describe the rationale for the review in the context of what is already known. & $47(100 \%)$ \\
\hline \multicolumn{4}{|l|}{ Methods } \\
\hline Protocol and registration & 5 & $\begin{array}{l}\text { Indicate if a review protocol exists, if and where it can be accessed (e.g., Web address), and, if available, } \\
\text { provide registration information including registration number. }\end{array}$ & $18(38.3 \%)$ \\
\hline Eligibility criteria & 6 & $\begin{array}{l}\text { Specify study characteristics (e.g., PICOS, length of follow-up) and report characteristics (e.g., years } \\
\text { considered, language, publication status) used as criteria for eligibility, giving rationale. }\end{array}$ & $46(97.9 \%)$ \\
\hline Information sources & 7 & $\begin{array}{l}\text { Describe all information sources (e.g., databases with dates of coverage, contact with study authors to } \\
\text { identify additional studies) in the search and date last searched. }\end{array}$ & $47(100 \%)$ \\
\hline Search & 8 & $\begin{array}{l}\text { Present full electronic search strategy for at least one database, including any limits used, } \\
\text { such that it could be repeated. }\end{array}$ & $47(100 \%)$ \\
\hline Study selection & 9 & $\begin{array}{l}\text { State the process for selecting studies (i.e., screening, eligibility, included in systematic review, and, } \\
\text { if applicable, included in the meta-analysis). }\end{array}$ & $47(100 \%)$ \\
\hline Data collection process & 10 & $\begin{array}{l}\text { Describe method of data extraction from reports (e.g., piloted forms, independently, in duplicate) and } \\
\text { any processes for obtaining and confirming data from investigators. }\end{array}$ & $47(100 \%)$ \\
\hline Data items & 11 & $\begin{array}{c}\text { List and define all variables for which data were sought (e.g., PICOS, funding sources) and any assumptions } \\
\text { and simplifications made. }\end{array}$ & $44(93.6 \%)$ \\
\hline Risk of bias in individual studies & 12 & $\begin{array}{l}\text { Describe methods used for assessing risk of bias of individual studies (including specification of whether this } \\
\text { was performed at the study or outcome level), and how this information is to be used in any data synthesis. }\end{array}$ & $28(59.6 \%)$ \\
\hline Summary measures & 13 & State the principal summary measures (e.g., risk ratio, difference in means). & $47(100 \%)$ \\
\hline Synthesis of results & 14 & $\begin{array}{l}\text { Describe the methods of handling data and combining results of studies, if performed, including measures of } \\
\text { consistency }\left(\text { e.g., } \mathrm{I}^{2}\right) \text { for each meta-analysis. }\end{array}$ & $47(100 \%)$ \\
\hline Risk of bias across studies & 15 & $\begin{array}{c}\text { Specify any assessment of risk of bias that may affect the cumulative evidence (e.g., publication bias, selective } \\
\text { reporting within studies). }\end{array}$ & $24(51.1 \%)$ \\
\hline Additional analyses & 16 & $\begin{array}{c}\text { Describe methods of additional analyses (e.g., sensitivity or subgroup analyses, meta-regression), if } \\
\text { performed, indicating which were pre-specified. }\end{array}$ & $19(40.4 \%)$ \\
\hline
\end{tabular}


Table A2. Cont.

\begin{tabular}{|c|c|c|c|}
\hline Section/Topic & $\#$ & Checklist Item-Yes if Reported & No $(\%)$ of Reports $(n=47)$ \\
\hline \multicolumn{4}{|l|}{ Results } \\
\hline Study selection & 17 & $\begin{array}{l}\text { Give numbers of studies screened, assessed for eligibility, and included in the review, with reasons for } \\
\text { exclusions at each stage, ideally with a flow diagram. }\end{array}$ & $46(97.9 \%)$ \\
\hline Study characteristics & 18 & $\begin{array}{l}\text { For each study, present characteristics for which data were extracted (e.g., study size, PICOS, follow-up } \\
\text { period) and provide the citations. }\end{array}$ & $46(97.9 \%)$ \\
\hline Risk of bias within studies & 19 & Present data on risk of bias of each study and, if available, any outcome level assessment (see item 12). & $28(59.6 \%)$ \\
\hline Synthesis of results & 21 & Present results of each meta-analysis performed, including confidence intervals and measures of consistency. & $47(100 \%)$ \\
\hline Risk of bias across studies & 22 & Present results of any assessment of risk of bias across studies (see Item 15). & $24(51.1 \%)$ \\
\hline Additional analysis & 23 & $\begin{array}{c}\text { Give results of additional analyses, if performed (e.g., sensitivity or subgroup analyses, meta-regression (see } \\
\text { Item 16). }\end{array}$ & $25(53.2 \%)$ \\
\hline \multicolumn{4}{|l|}{ Discussion } \\
\hline Summary of evidence & 24 & $\begin{array}{l}\text { Summarize the main findings including the strength of evidence for each main outcome; consider their } \\
\text { relevance to key groups (e.g., healthcare providers, users, and policy makers). }\end{array}$ & $47(100 \%)$ \\
\hline Limitations & 25 & $\begin{array}{l}\text { Discuss limitations at study and outcome level (e.g., risk of bias), and at review-level (e.g., incomplete } \\
\text { retrieval of identified research, reporting bias). }\end{array}$ & $47(100 \%)$ \\
\hline Conclusions & 26 & $\begin{array}{c}\text { Provide a general interpretation of the results in the context of other evidence, and implications for future } \\
\text { research. }\end{array}$ & $47(100 \%)$ \\
\hline \multicolumn{4}{|l|}{ Funding } \\
\hline Funding & 27 & $\begin{array}{c}\text { Describe sources of funding for the systematic review and other support (e.g., supply of data); role of funders } \\
\text { for the systematic review. }\end{array}$ & $10(21.3 \%)$ \\
\hline
\end{tabular}

Data are number (\%) of reports featuring the corresponding item. 


\section{Appendix C. A Total of 47 Included Studies in Reporting Quality Assessment}

Al-Mahrouqi MM, MacDonald DA, Vicenzino B, Smith MD. Physical impairments in adults with ankle osteoarthritis: a systematic review and meta-analysis. J Orthop Sports Phys Ther. 2018;48:449-459. https:/ / doi.org/10.2519/jospt.2018.7569.

Almeida MO, Davis IS, Lopes AD. Biomechanical differences of foot-strike patterns during running: a systematic review with meta-analysis. J Orthop Sports Phys Ther. 2015;45:738-755. https:/ / doi.org/10.2519/jospt.2015.6019.

Alsalaheen B, Stockdale K, Pechumer D, Broglio SP, Marchetti GF. A comparative metaanalysis of the effects of concussion on a computerized neurocognitive test and self-reported symptoms. J Athl Train. 2017;52:834-846. https://doi.org/10.4085/1062-6050-52.7.05.

Alzahrani H, Mackey M, Stamatakis E, Pinheiro MB, Wicks M, Shirley D. The effectiveness of incidental physical activity interventions compared to other interventions in the management of people with low back pain: a systematic review and meta-analysis of randomised controlled trials. Phys Ther Sport. 2019;36:34-42. https://doi.org/10.1016/j. ptsp.2018.12.008.

Armitano CN, Haegele JA, Russell DM. The use of augmented information for reducing anterior cruciate ligament injury risk during jump landings: a systematic review. J Athl Train. 2018;53:844-859. https:/ / doi.org/10.4085/1062-6050-320-17.

Basson A, Olivier B, Ellis R, Coppieters M, Stewart A, Mudzi W. The effectiveness of neural mobilization for neuromusculoskeletal conditions: a systematic review and metaanalysis. J Orthop Sports Phys Ther. 2017;47:593-615. https:/ / doi.org/10.2519/jospt.2017 .7117 .

Bullock GS, Faherty MS, Ledbetter L, Thigpen CA, Sell TC. Shoulder range of motion and baseball arm injuries: a systematic review and meta-analysis. J Athl Train. 2018;53:11901199. https://doi.org/10.4085/1062-6050-439-17.

Bunn PDS, Rodrigues AI, Bezerra da Silva E. The association between the functional movement screen outcome and the incidence of musculoskeletal injuries: a systematic review with meta-analysis. Phys Ther Sport. 2019;35:146-158. https://doi.org/10.1016/j. ptsp.2018.11.011.

Cayco CS, Labro AV, Gorgon EJR. Hold-relax and contract-relax stretching for hamstrings flexibility: a systematic review with meta-analysis. Phys Ther Sport. 2019 Jan;35:4255. https://doi.org/10.1016/j.ptsp.2018.11.001.

Chou LC, Liou TH, Kuan YC, Huang YH, Chen HC. Autologous blood injection for treatment of lateral epicondylosis: a meta-analysis of randomized controlled trials. Phys Ther Sport. 2016;18:68-73 https:/ / doi.org/10.1016/j.ptsp.2015.06.002.

Coburn SL, Barton CJ, Filbay SR, Hart HF, Rathleff MS, Crossley KM. Quality of life in individuals with patellofemoral pain: a systematic review including meta-analysis. Phys Ther Sport. 2018;33:96-108. https:/ / doi.org/10.1016/j.ptsp.2018.06.006.

Deasy M, Leahy E, Semciw AI. Hip strength deficits in people with symptomatic knee osteoarthritis: a systematic review with meta-analysis. J Orthop Sports Phys Ther. 2016;46:629-639. https:/ / doi.org/10.2519/jospt.2016.6618.

Den Bandt HL, Paulis WD, Beckwée D, Ickmans K, Nijs J, Voogt L. Pain mechanisms in low back pain: a systematic review with meta-analysis of mechanical quantitative sensory testing outcomes in people with nonspecific low back pain. J Orthop Sports Phys Ther. 2019;49:698-715. https://doi.org/10.2519/jospt.2019.8876.

Desjardins-Charbonneau A, Roy JS, Dionne CE, Frémont P, MacDermid JC, Desmeules F. The efficacy of manual therapy for rotator cuff tendinopathy: a systematic review and meta-analysis. J Orthop Sports Phys Ther. 2015;45:330-350. https://doi.org/10.2519/jospt. 2015.5455.

Desmeules F, Boudreault J, Roy JS, Dionne C, Frémont P, MacDermid JC. The efficacy of therapeutic ultrasound for rotator cuff tendinopathy: a systematic review and metaanalysis. Phys Ther Sport. 2015;16:276-284. https://doi.org/10.1016/j.ptsp.2014.09.004. 
Dix J, Marsh S, Dingenen B, Malliaras P. The relationship between hip muscle strength and dynamic knee valgus in asymptomatic females: a systematic review. Phys Ther Sport. 2019;37:197-209. https:/ / doi.org/10.1016/j.ptsp.2018.05.015.

Eckenrode BJ, Kietrys DM, Parrott JS. Effectiveness of manual therapy for pain and self-reported function in individuals with patellofemoral pain: systematic review and meta-analysis. J Orthop Sports Phys Ther. 2018;48:358-371. https:/ /doi.org/10.2519/jospt. 2018.7243.

Games KE, Sefton JM, Wilson AE. Whole-body vibration and blood flow and muscle oxygenation: a meta-analysis. J Athl Train. 2015;50:542-549. https://doi.org/10.4085/1062 -6050-50.2.09.

Gattie E, Cleland JA, Snodgrass S. The effectiveness of trigger point dry needling for musculoskeletal conditions by physical therapists: a systematic review and meta-analysis. J Orthop Sports Phys Ther. 2017;47:133-149. https://doi.org/10.2519/jospt.2017.7096.

Ghai S, Driller M, Ghai I. Effects of joint stabilizers on proprioception and stability: a systematic review and meta-analysis. Phys Ther Sport. 2017;25:65-75. https: / / doi.org/10 .1016/j.ptsp.2016.05.006.

Gomes-Neto M, Lopes JM, Conceição CS, et al. Stabilization exercise compared to general exercises or manual therapy for the management of low back pain: a systematic review and meta-analysis. Phys Ther Sport. 2017;23:136-142. https://doi.org/10.1016/j. ptsp.2016.08.004.

Jeong HS, Lee SC, Jee H, Song JB, Chang HS, Lee SY. Proprioceptive training and outcomes of patients with knee osteoarthritis: a meta-analysis of randomized controlled trials. J Athl Train. 2019;54:418-428. https:/ / doi.org/10.4085/1062-6050-329-17.

Kang FJ, Ou HL, Lin KY, Lin JJ. Serratus anterior and upper trapezius electromyographic analysis of the push-up plus exercise: a systematic review and meta-analysis. J Athl Train. 2019;54:1156-1164. https:/ / doi.org/10.4085/1062-6050-237-18.

Karsten M, Ribeiro GS, Esquivel MS, Matte DL. The effects of inspiratory muscle training with linear workload devices on the sports performance and cardiopulmonary function of athletes: a systematic review and meta-analysis. Phys Ther Sport. 2018 Nov;34:92-104. https: / / doi.org/10.1016/j.ptsp.2018.09.004.

Knapik J, Steelman R. Risk factors for injuries during military static-line airborne operations: a systematic review and meta-analysis. J Athl Train. 2016;51:962-980. https: / / doi.org/10.4085/1062-6050-51.9.10.

Lam OT, Strenger DM, Chan-Fee M, Pham PT, Preuss RA, Robbins SM. Effectiveness of the McKenzie method of mechanical diagnosis and therapy for treating low back pain: literature review with meta-analysis. J Orthop Sports Phys Ther. 2018;48:476-490. https: / / doi.org/10.2519/jospt.2018.7562.

Lima YL, Ferreira VMLM, de Paula Lima PO, Bezerra MA, de Oliveira RR, Almeida GPL. The association of ankle dorsiflexion and dynamic knee valgus: a systematic review and meta-analysis. Phys Ther Sport. 2018;29:61-69. https:/ / doi.org/10.1016/j.ptsp.2017.0 7.003 .

López López L, Torres JR, Rubio AO, Torres Sánchez I, Cabrera Martos I, Valenza MC. Effects of neurodynamic treatment on hamstrings flexibility: a systematic review and metaanalysis. Phys Ther Sport. 2019;40:244-250. https://doi.org/10.1016/j.ptsp.2019.10.005.

Mansfield CJ, Vanetten L, Willy R, Di Stasi SPPDO, Magnussen R, Briggs M. The effects of needling therapies on muscle force production: a systematic review and meta-analysis. J Orthop Sports Phys Ther. 2019;49:154-170. https://doi.org/10.2519/jospt.2019.8270.

McAuliffe S, Tabuena A, McCreesh K, O’Keeffe M, Hurley J, Comyns T, et al. Altered strength profile in Achilles tendinopathy: a systematic review and meta-analysis. J Athl Train. 2019;54:889-900. https: / / doi.org/10.4085/1062-6050-43-18.

Montalvo AM, Schneider DK, Webster KE, et al. Anterior cruciate ligament injury risk in sport: a systematic review and meta-analysis of injury incidence by sex and sport classification. J Athl Train. 2019;54:472-482. https:/ / doi.org/10.4085/1062-6050-407-16. 
Nae J, Creaby MW, Cronström A, Ageberg E. Measurement properties of visual rating of postural orientation errors of the lower extremity-A systematic review and meta-analysis. Phys Ther Sport. 2017;27:52-64. https://doi.org/10.1016/j.ptsp.2017.04.003.

Nascimento LR, Teixeira-Salmela LF, Souza RB, Resende RA. Hip and knee strengthening is more effective than knee strengthening alone for reducing pain and improving activity in individuals with patellofemoral pain: a systematic review with meta-analysis. J Orthop Sports Phys Ther. 2018;48:19-31. https:/ / doi.org/10.2519/jospt.2018.7365.

Neilson V, Ward S, Hume P, Lewis G, McDaid A. Effects of augmented feedback on training jump landing tasks for ACL injury prevention: a systematic review and metaanalysis. Phys Ther Sport. 2019 Sep;39:126-135. https:/ / doi.org/10.1016/j.ptsp.2019.07.00 4.

Perriman A, Leahy E, Semciw AI. The effect of open-versus closed-kinetic-chain exercises on anterior tibial laxity, strength, and function following anterior cruciate ligament reconstruction: a systematic review and meta-analysis. J Orthop Sports Phys Ther. 2018;48:552-566. https:/ / doi.org/10.2519/jospt.2018.7656.

Powden CJ, Hoch JM, Hoch MC. Rehabilitation and improvement of health-related quality-of-life detriments in individuals with chronic ankle instability: a meta-analysis. J Athl Train. 2017;52:753-765. https:/ / doi.org/10.4085/1062-6050-52.5.01.

Sales AT, Fregonezi GA, Ramsook AH, Guenette JA, Lima IN, Reid WD. Respiratory muscle endurance after training in athletes and non-athletes: A systematic review and meta-analysis. Phys Ther Sport. 2016;17:76-86. https:/ / doi.org/10.1016/j.ptsp.2015.08.001.

Sciascia A, Myers N, Kibler WB, Uhl TL. Return to preinjury levels of participation after superior labral repair in overhead athletes: a systematic review. J Athl Train. 2015;50:767777. https: / / doi.org/10.4085/1062-6050-50.3.06.

Seffrin CB, Cattano NM, Reed MA, Gardiner-Shires AM. Instrument-assisted soft tissue mobilization: a systematic review and effect size analysis. J Athl Train. 2019;54:808821. https: / / doi.org/10.4085/1062-6050-481-17.

Slater LV, Hart JM, Kelly AR, Kuenze CM. Progressive changes in walking kinematics and kinetics after anterior cruciate ligament injury and reconstruction: a review and metaanalysis. J Athl Train. 2017 Sep;52(9):847-860. https://doi.org/10.4085/1062-6050-52.6.06.

Slimani M, Bragazzi NL, Znazen H, Paravlic A, Azaiez F, Tod D. Psychosocial predictors and psychological prevention of soccer injuries: a systematic review and meta-analysis of the literature. Phys Ther Sport. 2018;32:293-300. https:/ / doi.org/10.1016/j.ptsp.2018.05. 006.

Takasaki H, Lim ECW, Soon B. The effect of shoulder muscle fatigue on active repositioning acuity and scapulothoracic resting alignment: a systematic review with metaanalysis. Phys Ther Sport. 2016;20:61-78. https://doi.org/10.1016/j.ptsp.2016.01.001.

Takeno K, Glaviano NR, Norte GE, Ingersoll CD. Therapeutic interventions for scapular kinematics and disability in patients with subacromial impingement: a systematic review. J Athl Train. 2019;54:283-295. https:/ / doi.org/10.4085/1062-6050-309-17.

Tsikopoulos K, Tsikopoulos A, Natsis K. Autologous whole blood or corticosteroid injections for the treatment of epicondylopathy and plantar fasciopathy? a systematic review and meta-analysis of randomized controlled trials. Phys Ther Sport. 2016;22:114122. https:// doi.org/10.1016/j.ptsp.2016.02.002.

Tsikopoulos K, Tsikopoulos I, Simeonidis E, et al. The clinical impact of platelet-rich plasma on tendinopathy compared to placebo or dry needling injections: a meta-analysis. Phys Ther Sport. 2016;17:87-94. https:/ / doi.org/10.1016/j.ptsp.2015.06.003.

Vallandingham RA, Gaven SL, Powden CJ. Changes in dorsiflexion and dynamic postural control after mobilizations in individuals with chronic ankle instability: a systematic review and meta-analysis. J Athl Train. 2019 Apr;54(4):403-417. https:/ / doi.org/10.4085/ 1062-6050-380-17.

Zhao R, Zhang M, Zhang Q. The effectiveness of combined exercise interventions for preventing postmenopausal bone loss: a systematic review and meta-analysis. J Orthop Sports Phys Ther. 2017;47:241-251. https://doi.org/10.2519/jospt.2017.6969. 


\section{References}

1. Jette, D.U.; Bacon, K.; Batty, C.; Carlson, M.; Ferland, A.; Hemingway, R.D.; Hill, J.C.; Ogilvie, L.; Volk, D. Evidence-based practice: Beliefs, attitudes, knowledge, and behaviors of physical therapists. Phys. Ther. 2003, 83, 786-805. [CrossRef]

2. Evidence-Based Medicine Working Group. Evidence-based medicine. A new approach to teaching the practice of medicine. JAMA 1992, 268, 2420-2425. [CrossRef]

3. Moseley, A.M.; Herbert, R.D.; Sherrington, C.; Maher, C.G. Evidence for physiotherapy practice: A survey of the Physiotherapy Evidence Database (PEDro). Aust. J. Physiother. 2002, 48, 43-49. [CrossRef]

4. Kurichi, J.E.; Sonnad, S.S. Statistical methods in the surgical literature. J. Am. Coll. Surg. 2006, 202, 476-484. [CrossRef]

5. Salbach, N.M.; Jaglal, S.B.; Korner-Bitensky, N.; Rappolt, S.; Davis, D. Practitioner and organizational barriers to evidence-based practice of physical therapists for people with stroke. Phys. Ther. 2007, 87, 1284-1303. [CrossRef] [PubMed]

6. Gopalakrishnan, S.; Ganeshkumar, P. Systematic reviews and meta-analysis: Understanding the best evidence in primary healthcare. J. Fam. Med. Prim. Care 2013, 2, 9-14.

7. Littell, J.H.; Corcoran, J.; Pillai, V. Systematic Reviews and Meta-Analysis; Oxford University Press: Oxford, UK, 2008.

8. Cooper, C.; Booth, A.; Varley-Campbell, J.; Britten, N.; Garside, R. Defining the process to literature searching in systematic reviews: A literature review of guidance and supporting studies. BMC Med. Res. Methodol. 2018, 18, 85. [CrossRef] [PubMed]

9. Ahn, E.; Kang, H. Introduction to systematic review and meta-analysis. Korean J. Anesthesiol. 2018, 71, 103-112. [CrossRef]

10. Harbour, R.; Miller, J. A new system for grading recommendations in evidence based guidelines. BMJ 2001, 323, 334-336. [CrossRef]

11. Shin, I.S. Recent Research Trends in Meta-analysis. Asian Nurs. Res. (Korean Soc. Nurs. Sci.) 2017, 11, 79-83. [CrossRef] [PubMed]

12. Borenstein, M.; Hedges, L.V.; Higgins, J.P.T.; Rothstein, H.R. Introduction to Meta-Analysis; Wiley: West Sussex, UK, 2009.

13. Murad, M.H.; Asi, N.; Alsawas, M.; Alahdab, F. New evidence pyramid. Evid. Based Med. 2016, 21, 125-127. [CrossRef] [PubMed]

14. Higgins, J.P.T.; Thomas, J.; Chandler, J.; Chandler, J.; Cumpston, M.; Li, T.; Page, M.; Welch, V. Cochrane Handbook for Systematic Reviews of Interventions (Version 6.2). Available online: https://training.cochrane.org/handbook/current/chapter-11/ (accessed on 22 July 2021).

15. Moher, D.; Liberati, A.; Tetzlaff, J.; Altman, D.G.; PRISMA Group. Preferred reporting items for systematic reviews and meta-analyses: The PRISMA statement. Ann. Intern. Med. 2009, 151, 264-269. [CrossRef] [PubMed]

16. Cullis, P.S.; Gudlaugsdottir, K.; Andrews, J. A systematic review of the quality of conduct and reporting of systematic reviews and meta-analyses in paediatric surgery. PLoS ONE 2017, 12, e0175213. [CrossRef]

17. Narayan, V.M.; Chrouser, K.; Haynes, R.B.; Parrish, R.; Dahm, P. Defining the publication source of high-quality evidence in urology: An analysis of EvidenceUpdates. BJU Int. 2016, 117, 861-866. [CrossRef] [PubMed]

18. Page, M.J.; Shamseer, L.; Altman, D.G.; Tetzlaff, J.; Sampson, M.; Tricco, A.C.; Catalá-López, F.; Li, L.; Reid, E.K.; Sarkis-Onofre, R.; et al. Epidemiology and reporting characteristics of systematic reviews of biomedical research: A cross-sectional study. PLoS Med. 2016, 13, e1002028. [CrossRef]

19. Padula, R.S.; Pires, R.S.; Alouche, S.R.; Chiavegato, L.D.; Lopes, A.D.; Costa, L.O. Analysis of reporting of systematic reviews in physical therapy published in Portuguese. Braz. J. Phys. Ther. 2012, 16, 381-388, (In English \& Portuguese). [CrossRef] [PubMed]

20. Beller, E.M.; Glasziou, P.P.; Altman, D.G.; Hopewell, S.; Bastian, H.; Chalmers, I.; Gøtzsche, P.C.; Lasserson, T.; Tovey, D.; PRISMA for Abstracts Group. PRISMA for abstracts: Reporting systematic reviews in journal and conference abstracts. PLoS Med. 2013, 10, e1001419. [CrossRef]

21. Liberati, A.; Altman, D.G.; Tetzlaff, J.; Mulrow, C.; Gøtzsche, P.C.; Ioannidis, J.P.; Clarke, M.; Devereaux, P.J.; Kleijnen, J.; Moher, D. The PRISMA statement for reporting systematic reviews and meta-analyses of studies that evaluate health care interventions: Explanation and elaboration. J. Clin. Epidemiol. 2009, 62, e1-e34. [CrossRef]

22. Tan, W.K.; Wigley, J.; Shantikumar, S. The reporting quality of systematic reviews and meta-analyses in vascular surgery needs improvement: A systematic review. Int. J. Surg. 2014, 12, 1262-1265. [CrossRef]

23. Clarivate Analytics. Journal Citation Reports. Available online: https://clarivate.com/webofsciencegroup/solutions/journalcitation-reports/ (accessed on 17 April 2021).

24. Tam, W.W.S.; Lo, K.K.H.; Khalechelvam, P. Endorsement of PRISMA statement and quality of systematic reviews and metaanalyses published in nursing journals: A cross-sectional study. BMJ Open 2017, 7, e013905. [CrossRef]

25. Liu, Y.; Zhang, R.; Huang, J.; Zhao, X.; Liu, D.; Sun, W.; Mai, Y.; Zhang, P.; Wang, Y.; Cao, H.; et al. Reporting quality of systematic reviews/meta-analyses of acupuncture. PLOS ONE 2014, 9, e113172. [CrossRef] [PubMed]

26. Ge, L.; Wang, J.C.; Li, J.L.; Liang, L.; An, N.; Shi, X.T.; Liu, Y.C.; Tian, J.H. The assessment of the quality of reporting of systematic reviews/meta-analyses in diagnostic tests published by authors in China. PLoS ONE 2014, 9, e85908. [CrossRef] [PubMed]

27. Pigott, T.D.; Polanin, J.R. Methodological guidance paper: High-quality meta-analysis in a systematic review. Rev. Educ. Res. 2020, 90, 24-46. [CrossRef]

28. Lima, Y.L.; Ferreira, V.M.L.M.; de Paula Lima, P.O.; Bezerra, M.A.; de Oliveira, R.R.; Almeida, G.P.L. The association of ankle dorsiflexion and dynamic knee valgus: A systematic review and meta-analysis. Phys. Ther. Sport 2018, 29, 61-69. [CrossRef] [PubMed]

29. Neilson, V.; Ward, S.; Hume, P.; Lewis, G.; McDaid, A. Effects of augmented feedback on training jump landing tasks for ACL injury prevention: A systematic review and meta-analysis. Phys. Ther. Sport 2019, 39, 126-135. [CrossRef] [PubMed] 
30. Stroup, D.F.; Berlin, J.A.; Morton, S.C.; Olkin, I.; Williamson, G.D.; Rennie, D.; Moher, D.; Becker, B.J.; Sipe, T.A.; Thacker, S.B. Meta-analysis of observational studies in epidemiology: A proposal for reporting. JAMA 2000, 283, 2008-2012. [CrossRef] [PubMed]

31. Powden, C.J.; Hoch, J.M.; Hoch, M.C. Rehabilitation and improvement of health-related quality-of-life detriments in individuals with chronic ankle instability: A meta-analysis. J. Athl. Train. 2017, 52, 753-765. [CrossRef]

32. Greenland, S.; Senn, S.J.; Rothman, K.J.; Carlin, J.B.; Poole, C.; Goodman, S.N.; Altman, D.G. Statistical tests, P values, confidence intervals, and power: A guide to misinterpretations. Eur. J. Epidemiol. 2016, 31, 337-350. [CrossRef]

33. National Institute for Health Research. PROSPERO is Fast-Tracking Registration of Protocols Related to COVID-19 2021. Available online: https:/ / www.crd.york.ac.uk/prospero/ (accessed on 22 July 2021).

34. Tawfik, G.M.; Giang, H.; Ghozy, S.; Altibi, A.M.; Kandil, H.; Le, H.H.; Eid, P.S.; Radwan, I.; Makram, O.M.; Hien, T.; et al. Protocol registration issues of systematic review and meta-analysis studies: A survey of global researchers. BMC Med. Res. Methodol. 2020, 20, 213. [CrossRef]

35. Booth, A.; Clarke, M.; Ghersi, D.; Moher, D.; Petticrew, M.; Stewart, L. An international registry of systematic-review protocols. Lancet 2011, 377, 108-109. [CrossRef]

36. Booth, A. Providing transparency in systematic review methods: The case for protocol registration. Gerodontology 2019, 36, 301-302. [CrossRef]

37. Shantikumar, S.; Wigley, J.; Hameed, W.; Handa, A. A survey of instructions to authors in surgical journals on reporting by CONSORT and PRISMA. Ann. R Coll. Surg. Engl. 2012, 94, 468-471. [CrossRef]

38. Walker, E.; Hernandez, A.V.; Kattan, M.W. Meta-analysis: Its strengths and limitations. Clevel. Clin. J. Med. 2008, 75, 431-439. [CrossRef]

39. Luchini, C.; Veronese, N.; Nottegar, A.; Shin, J.I.; Gentile, G.; Granziol, U.; Soysal, P.; Alexinschi, O.; Smith, L.; Solmi, M. Assessing the quality of studies in meta-research: Review/guidelines on the most important quality assessment tools. Pharm. Stat. 2021, 20, 185-195. [CrossRef]

40. Appelbaum, M.; Cooper, H.; Kline, R.B.; Mayo-Wilson, E.; Nezu, A.M.; Rao, S.M. Journal article reporting standards for quantitative research in psychology: The APA publications and Communications Board task force report. Am. Psychol. 2018, 73, 3-25. [CrossRef]

41. Haidich, A.B. Meta-analysis in medical research. Hippokratia 2010, 14 (Suppl. 1), $29-37$.

42. Alzahrani, H.; Mackey, M.; Stamatakis, E.; Pinheiro, M.B.; Wicks, M.; Shirley, D. The effectiveness of incidental physical activity interventions compared to other interventions in the management of people with low back pain: A systematic review and meta-analysis of randomised controlled trials. Phys Ther. Sport 2019, 36, 34-42. [CrossRef] [PubMed]

43. Atkins, D.; Best, D.; Briss, P.A.; Eccles, M.; Falck-Ytter, Y.; Flottorp, S.; Guyatt, G.H.; Harbour, R.T.; Haugh, M.C.; Henry, D.; et al. Grading quality of evidence and strength of recommendations. BMJ 2004, 328, 1490. [PubMed]

44. Atkins, D.; Eccles, M.; Flottorp, S.; Guyatt, G.H.; Henry, D.; Hill, S.; Liberati, A.; O'Connell, D.; Oxman, A.D.; Phillips, B.; et al Systems for grading the quality of evidence and the strength of recommendations I: Critical appraisal of existing approaches The GRADE Working Group. BMC Health Serv. Res. 2004, 4, 38. [CrossRef] [PubMed]

45. Furlan, A.D.; Malmivaara, A.; Chou, R.; Maher, C.G.; Deyo, R.A.; Schoene, M.; Bronfort, G.; van Tulder, M.W.; Editorial Board of the Cochrane Back, Neck Group. 2015 updated method guideline for systematic reviews in the Cochrane Back and Neck Group. Spine 2015, 40, 1660-1673. [CrossRef] [PubMed]

46. Singh, J.A.; Wells, G.A.; Christensen, R.; Tanjong Ghogomu, E.; Maxwell, L.; Macdonald, J.K.; Filippini, G.; Skoetz, N.; Francis, D.; Lopes, L.C.; et al. Adverse effects of biologics: A network meta-analysis and Cochrane overview. Cochrane Database Syst. Rev. 2011, 2011, CD008794. [CrossRef]

47. Cochrane Training. Completing "Summary of Findings" Tables and Grading the Certainty of the Evidence. Available online: https: / / training.cochrane.org/handbook/current/chapter-14 (accessed on 21 April 2021).

48. Krimsky, S. Do Financial Conflicts of Interest Bias Research? An Inquiry into the "Funding Effect" Hypothesis. Sci. Technol. Hum. Values 2013, 38, 1-22. [CrossRef]

49. Kwak, S.M.; Myung, S.K.; Lee, Y.J.; Seo, H.G.; Korean Meta-Analysis Study Group. Efficacy of omega-3 fatty acid supplements (eicosapentaenoic acid and docosahexaenoic acid) in the secondary prevention of cardiovascular disease: A meta-analysis of randomized, double-blind, placebo-controlled trials. Arch. Intern. Med. 2012, 172, 686-694. [PubMed]

50. Myung, S.K.; Ju, W.; McDonnell, D.D.; Lee, Y.J.; Kazinets, G.; Cheng, C.T.; Moskowitz, J.M. Mobile phone use and risk of tumors: A meta-analysis. J. Clin. Oncol. 2009, 27, 5565-5572. [CrossRef] [PubMed]

51. Tandel, K.R. Sugar substitutes: Health controversy over perceived benefits. J. Pharm. Pharm. 2011, 2, 236-243. [CrossRef] [PubMed]

52. Helfer, B.; Prosser, A.; Samara, M.T.; Geddes, J.R.; Cipriani, A.; Davis, J.M.; Mavridis, D.; Salanti, G.; Leucht, S. Recent metaanalyses neglect previous systematic reviews and meta-analyses about the same topic: A systematic examination. BMC Med. 2015, 13, 82. [CrossRef]

53. Bigna, J.J.R.; Um, L.N.; Nansseu, J.R.N. A comparison of quality of abstracts of systematic reviews including meta-analysis of randomized controlled trials in high-impact general medicine journals before and after the publication of PRISMA extension for abstracts: A systematic review and meta-analysis. Syst. Rev. 2016, 5, 174. [PubMed] 
54. MacDonald, S.L.; Canfield, S.E.; Fesperman, S.F.; Dahm, P. Assessment of the methodological quality of systematic reviews published in the urological literature from 1998 to 2008. J. Urol. 2010, 184, 648-653. [CrossRef]

55. Braga, L.H.; Pemberton, J.; Demaria, J.; Lorenzo, A.J. Methodological concerns and quality appraisal of contemporary systematic reviews and meta-analyses in pediatric urology. J. Urol. 2011, 186, 266-271. [CrossRef]

56. Page, M.J.; Moher, D. Evaluations of the uptake and impact of the Preferred Reporting Items for Systematic reviews and Meta Analyses (PRISMA) Statement and extensions: A scoping review. Syst. Rev. 2017, 6, 263. [CrossRef]

57. Mayo-Wilson, E.; Heyward, J.; Keyes, A.; Reynolds, J.; White, S.; Atri, N.; Alexander, G.C.; Omar, A.; Ford, D.E.; National Clinical Trials Registration and Results Reporting Taskforce Survey Subcommittee. Clinical trial registration and reporting: A survey of academic organizations in the United States. BMC Med. 2018, 16, 60. [CrossRef] [PubMed]

58. Oliveira, C.B.; Elkins, M.R.; Lemes, Í.R.; de Oliveira Silva, D.; Briani, R.V.; Monteiro, H.L.; Azevedo, F.M.; Pinto, R.Z. A low proportion of systematic reviews in physical therapy are registered: A survey of 150 published systematic reviews. Braz. J. Phys. Ther. 2018, 22, 177-183. [CrossRef] [PubMed]

59. Hartling, L.; Ospina, M.; Liang, Y.; Dryden, D.M.; Hooton, N.; Seida, J.K.; Klassen, T.P. Risk of bias versus quality assessment of randomised controlled trials: Cross sectional study. BMJ 2009, 339, b4012. [CrossRef]

60. Deeks, J.J.; Dinnes, J.; D’Amico, R.; Sowden, A.J.; Sakarovitch, C.; Song, F.; Petticrew, M.; Altman, D.G.; International Stroke Trial Collaborative Group; European Carotid Surgery Trial Collaborative Group. Evaluating non-randomised intervention studies. Health Technol. Assess. 2003, 7, 1-173. [CrossRef] [PubMed]

61. Kim, S.Y.; Park, J.E.; Lee, Y.J.; Seo, H.J.; Sheen, S.S.; Hahn, S.; Jang, B.H.; Son, H.J. Testing a tool for assessing the risk of bias for non-randomized studies showed moderate reliability and promising validity. J. Clin. Epidemiol. 2013, 66, 408-414. [CrossRef]

62. Schulz, K.F.; Altman, D.G.; Moher, D.; CONSORT Group. CONSORT 2010 statement: Updated guidelines for reporting parallel group randomized trials. Ann. Intern. Med. 2010, 152, 726-732. [CrossRef]

63. Vandenbroucke, J.P.; Von Elm, E.; Altman, D.G.; Gøtzsche, P.C.; Mulrow, C.D.; Pocock, S.J. Strengthening the Reporting of Observational Studies in Epidemiology (STROBE) statement: Guidelines for reporting observational studies. BMJ 2007, 335, 806-808. [CrossRef]

64. De Morton, N.A. The PEDro scale is a valid measure of the methodological quality of clinical trials: A demographic study. Aust. J. Physiother. 2009, 55, 129-133. [CrossRef]

65. Alsalaheen, B.; Stockdale, K.; Pechumer, D.; Broglio, S.P.; Marchetti, G.F. A comparative meta-analysis of the effects of concussion on a computerized neurocognitive test and self-reported symptoms. J. Athl. Train. 2017, 52, 834-846. [CrossRef]

66. Hoyt, W.T.; Del Re, A.C. Effect size calculation in meta-analyses of psychotherapy outcome research. Psychother. Res. 2018, 28, 379-388. [CrossRef]

67. Slater, L.V.; Hart, J.M.; Kelly, A.R.; Kuenze, C.M. Progressive changes in walking kinematics and kinetics after anterior cruciate ligament injury and reconstruction: A review and meta-analysis. J. Athl. Train. 2017, 52, 847-860. [CrossRef] [PubMed]

68. Seffrin, C.B.; Cattano, N.M.; Reed, M.A.; Gardiner-Shires, A.M. Instrument-assisted soft tissue mobilization: A systematic review and effect-size analysis. J. Athl. Train. 2019, 54, 808-821. [CrossRef] [PubMed]

69. McAuliffe, S.; Tabuena, A.; McCreesh, K.; O'Keeffe, M.; Hurley, J.; Comyns, T.; Purtill, H.; O'Neill, S.; O'Sullivan, K. Altered strength profile in Achilles tendinopathy: A systematic review and meta-analysis. J. Athl. Train. 2019, 54, 889-900. [CrossRef] [PubMed]

70. Olejnik, S.; Algina, J. Measures of effect size for comparative studies: Applications, interpretations, and limitations. Contemp. Educ. Psychol. 2000, 25, 241-286. [CrossRef] [PubMed]

71. Beeson, P.M.; Robey, R.R. Evaluating single-subject treatment research: Lessons learned from the aphasia literature. Neuropsychol. Rev. 2006, 16, 161-169. [CrossRef] [PubMed]

72. Knapik, J.; Steelman, R. Risk factors for injuries during military static-line airborne operations: A systematic review and meta-analysis. J. Athl. Train. 2016, 51, 962-980. [CrossRef]

73. Hedges, L.V.; Olkin, I. Statistical Methods for Meta-Analysis; Academic Press: Cambridge, MA, USA, 1985.

74. McGuinness, L.A.; Higgins, J.P.T. Risk-of-bias VISualization (robvis): An R package and Shiny web app for visualizing risk-of-bias assessments. Res. Synth. Methods 2021, 12, 55-61. [CrossRef]

75. Shea, B.J.; Reeves, B.C.; Wells, G.; Thuku, M.; Hamel, C.; Moran, J.; Moher, D.; Tugwell, P.; Welch, V.; Kristjansson, E.; et al. AMSTAR 2: A critical appraisal tool for systematic reviews that include randomised or non-randomised studies of healthcare interventions, or both. BMJ 2017, 358, j4008. [CrossRef]

76. Sterne, J.A.C.; Hernán, M.A.; McAleenan, A.; Reeves, B.C.; Higgins, J.P.T. Chapter 25: Assessing risk of bias in a non-randomized study. In Cochrane Handbook for Systematic Reviews of Interventions; Version 6.1; Higgins, J., Thomas, J., Chandler, J., Cumpston, M., Li, T., Page, M.J., Welch, V.A., Eds.; Wiley-Balckwell: Hoboken, NJ, USA, 2020. Available online: www.training.cochrane.org/ handbook (accessed on 22 July 2021). 